\title{
Expression of COUP-TFII Nuclear Receptor in Restricted GABAergic Neuronal Populations in the Adult Rat Hippocampus
}

\author{
Pablo Fuentealba, ${ }^{1,2}$ Thomas Klausberger, ${ }^{1,3}$ Theofanis Karayannis, ${ }^{1}$ Wai Yee Suen, ${ }^{1}$ Jojanneke Huck, ${ }^{1}$ \\ Ryohei Tomioka, ${ }^{1,4}$ Kathleen Rockland, ${ }^{4}$ Marco Capogna, ${ }^{1}$ Michèle Studer, ${ }^{5}$ Marisela Morales, ${ }^{6}$ and Peter Somogyi ${ }^{1}$ \\ ${ }^{1}$ Medical Research Council Anatomical Neuropharmacology Unit, University of Oxford, Oxford OX1 3TH, United Kingdom, ${ }^{2}$ Centro de Neurociencias, \\ Pontificia Universidad Catolica de Chile, Escuela de Medicina, Departamentos de Neurologia y Psiquiatria, Santiago, Chile, ${ }^{3}$ Center for Brain Research, \\ Medical University of Vienna, 1090 Vienna, Austria, ${ }^{4}$ Laboratory of Cortical Organization and Systematics, RIKEN Brain Science Institute, Wako, Saitama \\ 351-0198, Japan, ${ }^{5}$ Telethon Institute of Genetics and Medicine, 80131 Napoli, Italy, and ${ }^{6}$ National Institute on Drug Abuse-National Institutes of Health, \\ Baltimore, Maryland 22124
}

The COUP-TFII nuclear receptor, also known as NR2F2, is expressed in the developing ventral telencephalon and modulates the tangential migration of a set of subpallial neuronal progenitors during forebrain development. Little information is available about its expression patterns in the adult brain. We have identified the cell populations expressing COUP-TFII and the contribution of some of them to network activity in vivo. Expression of COUP-TFII by hippocampal pyramidal and dentate granule cells, as well as neurons in the neocortex, formed a gradient increasing from undetectable in the dorsal to very strong in the ventral sectors. In the dorsal hippocampal CA1 area, COUP-TFII was restricted to GABAergic interneurons and expressed in several, largely nonoverlapping neuronal populations. Immunoreactivity was present in calretinin-, neuronal nitric oxide synthase-, and reelin-expressing cells, as well as in subsets of cholecystokinin- or calbindin-expressing or radiatum-retrohippocampally projecting GABAergic cells, but not in parvalbumin- and/or somatostatin-expressing interneurons. In vivo recording and juxtacellular labeling of COUP-TFII-expressing cells revealed neurogliaform cells, basket cells in stratum radiatum and tachykinin-expressing radiatum dentate innervating interneurons, identified by their axodendritic distributions. They showed cell type-selective phase-locked firing to the theta rhythm but no activation during sharp wave/ripple oscillations. These basket cells in stratum radiatum and neurogliaform cells fired at the peak of theta oscillations detected extracellularly in stratum pyramidale, unlike previously reported ivy cells, which fired at the trough. The characterization of COUP-TFII-expressing neurons suggests that this developmentally important transcription factor plays cell type-specific role(s) in the adult hippocampus.

\section{Introduction}

Interneurons are fundamental components of cortical microcircuits, as they are implicated in the generation of population rhythms (Cobb et al., 1995; Buzsáki, 2002; Bartos et al., 2007)

Received Aug. 26, 2009; revised Nov. 14, 2009; accepted Dec. 8, 2009.

This work was supported by INTERDEVO (LSHM-CT-2004-005139) in the Framework 6 program of the European Union. We thank Kristina Detzner, Ben Micklem, and David Roberts for excellent technical assistance, and Dr. Laszlo Márton for computing. We thank the following scientists for their generous gift of antibodies (to molecules indicated in parentheses): A. Beggs ( $\alpha$-actinin-2), G. Ohning (CCK), K. G. Baimbridge (parvalbumin), A. Buchan (somatostatin), T. Gorcs (VIP), T. Kaneko (PPTB, Pro-ENK), E. Mugnaini (GAD), W. Sieghart (GABA $\left.A_{A} R-\alpha 1\right)$, A. Varro (pro-CCK), R. Shigemoto (NK1R), S. El Mestikawy (vGluT3), and M. Watanabe (CB1 receptor, vGluT3). Antibody 9303 was raised against CCK and provided by Citizens United in Research for in Epilepsy/Digestive Diseases Research Center, Antibody/RIA Core, National Institutes of Health Grant DK41301.

Correspondence should be addressed to either of the following: Pablo Fuentealba, Fundació Sant Joan de Déu, C/ Santa Rosa 39-57, 4a planta, Edifici Docent, 08950, Esplugues de Llobregat, Barcelona, Spain, E-mail: pjfd@hotmail.com; or Peter Somogyi, Medical Research Council Anatomical Neuropharmacology Unit, University of Oxford, 0xford 0X13TH, UK, E-mail: peter.somogyi@pharm.ox.ac.uk.

T. Karayannis' present address: Smilow Neuroscience Program, New York University School of Medicine, 522 1st Avenue, New York, NY 10016.

M. Studer's present address: Inserm U636, Université de Nice Sophia Antipolis, Faculté des Sciences, Centre de Biochimie, 06108 Nice, France.

DOI:10.1523/JNEUROSCI.4199-09.2010

Copyright $\odot 2010$ the authors $\quad 0270-6474 / 10 / 301595-15 \$ 15.00 / 0$ underlying various cognitive processes (Singer and Gray, 1995; Rodriguez et al., 1999). The tasks performed by GABAergic interneurons led to the development of many distinct cell types, even though their proportion is far smaller than that of pyramidal cells (Freund and Buzsáki, 1996; Kawaguchi and Kubota, 1997). The identification of interneurons has proved to be difficult partly due to the significant overlap in molecular markers between cell types. These molecules include $\mathrm{Ca}^{2+}$-binding proteins, such as calretinin (CR), calbindin (CB) and parvalbumin (PV); and neuropeptides, like cholecystokinin (CCK), neuropeptide Y (NPY) and somatostatin (SM) (Freund and Buzsáki, 1996; Kawaguchi and Kondo, 2002).

The diversity of GABAergic cells is generated at early embryonic stages in the ventral telencephalon (Flames and Marín, 2005; Wonders and Anderson, 2006), and their functional maturation requires cell type-specific transcription factors (Sugiyama et al., 2008). In rodents, most GABAergic cortical cells originate from subpallial progenitors in the medial (MGE) and caudal ganglionic eminence (CGE) and migrate to the pallium, where their differentiation is governed by combinations of transcription factors (Marín and Rubenstein, 2001, 2003; Batista-Brito and 
Fishell, 2009). For example, the Dlx transcription factors have migration-permissive and interneuron specification roles for MGE and CGE cells, and Lhx6 activity is required for the specification of PV- or SM-expressing interneurons (Liodis et al., 2007). The MGE gives rise to PV-, SM- and NPY-expressing cells, whereas the CGE generates mostly CR-expressing cells (Nery et al., 2002; Xu et al., 2004; Butt et al., 2005). Furthermore, only MGE progenitors express Nkx2.1, and disrupting the gene encoding it leads to a loss of MGE-derived and concomitant respecification of CGE-derived interneurons (Sussel et al., 1999; Butt et al., 2008).

The COUP-TF transcription factors are involved in neurogenesis, axogenesis, differentiation and cortical area patterning (Park et al., 2003; Armentano et al., 2007; Kim et al., 2009). The two members, COUP-TFI and COUP-TFI, appear to control dorsoventral migration of different neural progenitors in the telencephalon (Tripodi et al., 2004; Kanatani et al., 2008). Accordingly, COUP-TFI is expressed in subsets of migrating GABAergic interneurons, whereas COUP-TFII is expressed in Cajal-Retzius cells (Tripodi et al., 2004) and some caudally migrating interneurons (Kanatani et al., 2008).

The above examples suggest that the diversity of GABAergic cell types is specified by the temporally specific action of distinct combinations of transcription factors expressed in immature GABAergic neurons. Little is known about the expression patterns and further roles of developmentally important transcription factors in the adult brain (Kanatani et al., 2008). Do they contribute to the maintenance of interneuron type-specific function in the same sets of cells that expressed them during development? Can their adult expression pattern help to define adult GABAergic cell types and inform on their origin? Here, we have studied the neuron type-specific expression of COUP-TFII concentrating on the adult hippocampus. Following the identification of some COUP-TFII-immunopositive GABAergic neurons we also established their involvement in network activity.

\section{Materials and Methods}

All procedures involving experimental animals were performed in accordance with the Animals (Scientific Procedures) Act, 1986 (UK) and associated procedures.

Tissue preparation. For in situ hybridization, adult Sprague Dawley male rats (300-350 g body weight) were anesthetized with chloral hydrate $(35 \mathrm{mg} / 100 \mathrm{~g})$ and perfused transcardially with $4 \%(\mathrm{w} / \mathrm{v})$ paraformaldehyde in $0.1 \mathrm{~m}$ phosphate buffer (PB), $\mathrm{pH}$ 7.3. Brains were left in $4 \%$ paraformaldehyde for $2 \mathrm{~h}$ at $4^{\circ} \mathrm{C}$, rinsed with $\mathrm{PB}$ and transferred sequentially to $12 \%, 14 \%$ and $18 \%$ sucrose solutions in PB. Coronal serial cryostat sections of $20 \mu \mathrm{m}$ thickness were cut, washed in PB and processed.

For immunohistochemical reactions, adult Sprague Dawley male rats (250-350 g body weight) were deeply anesthetized with ketamine and xylazine ( 30 and $3 \mathrm{mg} / \mathrm{kg}$, respectively) and perfused transcardially with saline solution, followed by $20-30$ min fixation with a fixative of $4 \%$ paraformaldehyde, $15 \% \mathrm{v} / \mathrm{v}$ saturated picric acid, and $0.05 \%$ glutaraldehyde in $0.1 \mathrm{M} \mathrm{PB}, \mathrm{pH}$ 7.3. Coronal serial sections of $70 \mu \mathrm{m}$ thickness were then prepared. Mixtures of up to four primary antibodies raised in different species were used, as they are listed in supplemental Table 1 (available at www.jneurosci.org as supplemental material). The tyramide signal amplification method was used to study the colocalization of COUP-TFII, cholecystokinin (CCK), parvalbumin (PV) and SM, making it possible to detect two molecules with primary antibodies raised in the same species. Briefly, SM was detected with a very low concentration of mouse monoclonal primary antibody (diluted 1:50,000-1:100,000) incubated overnight and then incubated with a biotinylated-secondary antibody (1:100) overnight, followed by avidin-biotinylated-horseradish peroxidase complex for $1 \mathrm{~d}$ (ABC elite kit, Vector Laboratories). Next, a horseradish peroxidase enzyme reaction was performed with biotinylated- tyramide (TSA INDIRECT, PerkinElmer Life Sciences, 1:1000-1:3000) for $1 \mathrm{~h}$; which was then revealed with streptavidin conjugated to a fluorophore (see next paragraph) incubated overnight. Next, the standard inmmunoreaction protocol was followed to detect the other molecules (COUP-TFII, monoclonal mouse antibody; CCK, rabbit antibody and $\mathrm{PV}$, guinea pig antibody) in the same tissue. Secondary antibodies were conjugated to Alexa Fluor 488 (Invitrogen), AMCA, Cy3 or Cy5 (Jackson ImmunoResearch Laboratories).

Cells in the vascular system, in both the endothelial and mesenchymal compartments, express COUP-TFII, which is critical for angiogenesis and heart development (Pereira et al., 1999). However, these cells were much smaller than neurons and could be easily distinguished (Figs. 1-4) and were not included in our analysis.

Combined radioactive in situ hybridization and immunocytochemistry labeling. As described previously (Morales and Bloom, 1997), freefloating cryosections were incubated in PB supplemented with $0.5 \%$ Triton $\mathrm{X}-100$ for $10 \mathrm{~min}$, rinsed twice for 5 min each with $\mathrm{PB}$, treated with $0.2 \mathrm{~N} \mathrm{HCl}$ for $10 \mathrm{~min}$, rinsed twice for 5 min each with $\mathrm{PB}$, and then acetylated in $0.25 \%$ acetic anhydride in $0.1 \mathrm{~m}$ triethanolamine, $\mathrm{pH} 8.0$, for $10 \mathrm{~min}$. Sections were rinsed twice for $5 \mathrm{~min}$ each with $\mathrm{PB}$ and postfixed with $4 \%$ paraformaldehyde for $10 \mathrm{~min}$, and after a final rinse with $\mathrm{PB}$, sections were prehybridized for $3 \mathrm{~h}$ at $55^{\circ} \mathrm{C}$ in hybridization buffer $(50 \%$ formamide, $10 \%$ dextran sulfate, $5 \times$ Denhardt's solution, $0.62 \mathrm{M} \mathrm{NaCl}$, $50 \mathrm{~mm}$ dithiothreitol, 10 mм EDTA, 20 mм PIPES, pH 6.8, 0.2\% SDS, 250 $\mu \mathrm{g} / \mathrm{ml} \mathrm{ssDNA}, 250 \mu \mathrm{g} / \mathrm{ml}$ tRNA). After prehybridization, sections were hybridized at $55^{\circ} \mathrm{C}$ for $16 \mathrm{~h}$ in hybridization buffer containing $\left[{ }^{35} \mathrm{~S}\right]$ - and $\left[{ }^{33} \mathrm{P}\right]$-labeled single-stranded RNA probes at $10^{7} \mathrm{cpm} / \mathrm{ml}$ for GAD-65 (nucleotides 1-1758, GenBank Accession No. NM012563) and GAD-67 (nucleotides 1-1782, GenBank Accession No. NM017007). Sections were treated with RNase A at $4 \mu \mathrm{g} / \mathrm{ml}$ at $37^{\circ} \mathrm{C}$ for $1 \mathrm{~h}$, washed in $1 \times \mathrm{SSC}, 50 \%$ formamide at $55^{\circ} \mathrm{C}$ for $2 \mathrm{~h}$, and in $0.1 \times$ SSC at $68^{\circ} \mathrm{C}$ for $1 \mathrm{~h}$. For immunohistochemistry, the sections were rinsed with $\mathrm{PB}$, incubated in $1 \%$ bovine serum albumin (BSA) supplemented with $0.3 \%$ Triton X-100 in $\mathrm{PB}$ for $1 \mathrm{~h}$, and then incubated in 1:200 dilution of the mouse monoclonal anti-human COUP-TFII antibody for $24 \mathrm{~h}$ at $4^{\circ} \mathrm{C}$, followed by a 1:200 dilution of the anti-mouse biotinylated secondary antibody. After the sections were rinsed three times for $10 \mathrm{~min}$ each in $\mathrm{PB}$, they were processed with an ABC kit (Vector Laboratories). Samples were rinsed, and the peroxidase reaction was developed with $0.05 \%$ 3,3-diaminobenzidine- $4 \mathrm{HCl}(\mathrm{DAB})$ and $0.003 \% \mathrm{H}_{2} \mathrm{O}_{2}$. All antibody dilutions were performed in PB supplemented with 1\% BSA and 0.3\% Triton X-100. Sections were mounted on gelatin-coated slides, air-dried, dipped in nuclear track emulsion, and exposed for several weeks before development. The material was photographed under bright-field or epiluminescence microscopy.

Nonradioactive in situ hybridization-immunocytochemistry labeling. For nonradioactive hybridization, cryosections were processed as indicated for radioactive hybridization but hybridization was performed with hybridization buffer containing $600 \mathrm{ng}$ of a mix of GAD-65 and GAD-67 digoxigenin-labeled antisense riboprobes. The antisense digoxigenin riboprobes for $\mathrm{GAD}_{65}$ and $\mathrm{GAD}_{67}$ had the same sequence as described above and were obtained by in vitro transcription using digoxigenin-11-UTP labeling mix (Roche), and T3 RNA polymerase. Plasmids that contained the sequences for $\mathrm{GAD}_{65}$ and $\mathrm{GAD}_{67}$ were generously provided by Dr. Allan Tobin (University of California Los Angeles, Los Angeles, CA). Sections were treated with $4 \mu \mathrm{g} / \mathrm{ml} \mathrm{RNase} \mathrm{A} \mathrm{at} 37^{\circ} \mathrm{C}$ for $1 \mathrm{~h}$, washed with $1 \times \mathrm{SSC}, 50 \%$ formamide at $55^{\circ} \mathrm{C}$ for $1 \mathrm{~h}$, and with $0.1 \times$ SSC at $68^{\circ} \mathrm{C}$ for $1 \mathrm{~h}$. After the last SSC wash, sections were rinsed with TBS buffer ( $20 \mathrm{~mm}$ Tris- $\mathrm{HCl}, 0.5 \mathrm{M} \mathrm{NaCl}, \mathrm{pH}$ 8.2). Afterward, sections were incubated in 1:200 dilution of the mouse monoclonal anti-human COUP-TFII and antibody-antigen complexes detected as detailed under radioactive in situ hybridization. Sections were mounted on slides, air-dried and photographed to map the COUP-TFII-immunopositive nuclei. Slides were then incubated with an alkaline phosphataseconjugated antibody against digoxigenin (Roche Applied Science) overnight at $4^{\circ} \mathrm{C}$; the alkaline phosphatase reaction was developed with nitroblue tetrazolium and 5-bromo-4-chloro-3-indolyl phosphate (Roche Applied Science) yielding a purple reaction product. After rephotographing the sections the two labels were compared. 


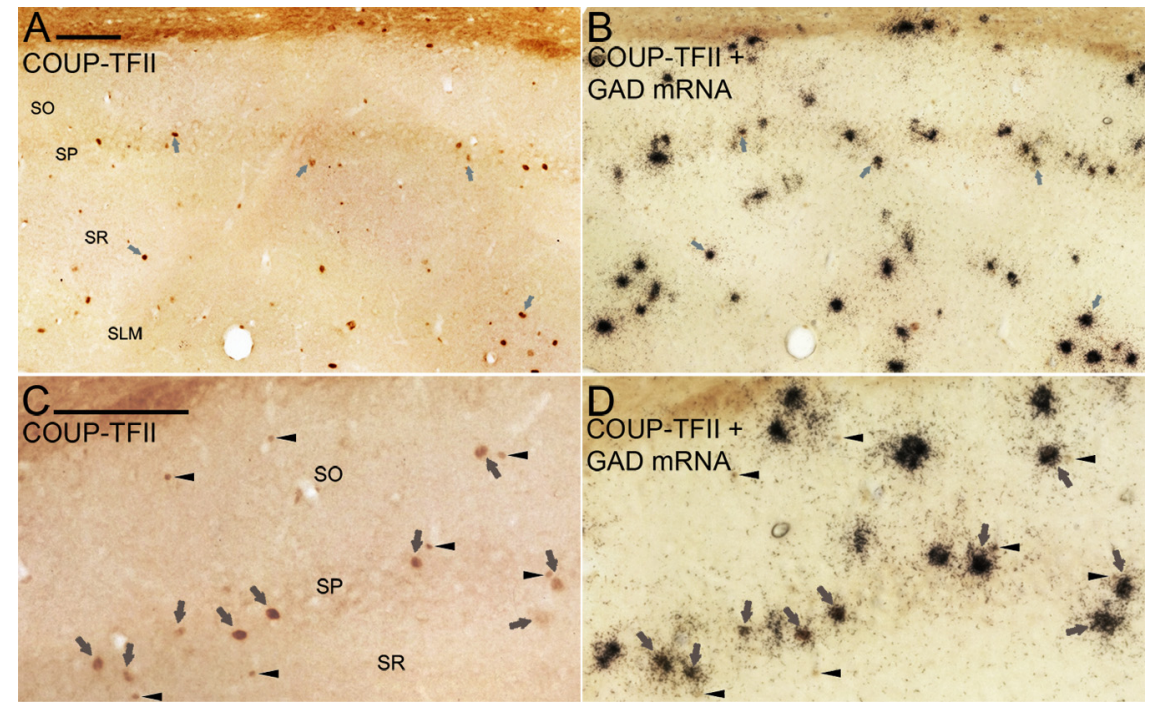

Figure 1. Some GABAergic cells selectively express COUP-TFIl in the dorsal hippocampus. $A, C$, Immunolabeling for COUP-TFII shows neuronal nuclei immunopositive for horseradish peroxidase product in all layers (arrows) at two magnifications. $\boldsymbol{B}, \boldsymbol{D}$, Expression of mRNA for GAD as detected by an antisense radioactive riboprobe recognizing both GAD-65 and GAD-67 isoforms. Note varying levels of expression of both COUP-TFIl and GAD mRNA in different cells. Small immunolabeled nuclei (arrowheads in $C, D)$ are perivascular cells that do not express GAD. The white matter labeling at top of $\boldsymbol{A}, \boldsymbol{B}$ and upper left of $\boldsymbol{C}, \boldsymbol{D}$ is not specific immunoreactivity. SO, stratum oriens; SP, stratum pyramidale; SR, stratum radiatum; SLM, stratum lacunosum-moleculare. Scale bars: $(A, C), 100 \mu \mathrm{m}$.

Preparation and injection of recombinant adenovirus vector. Experimental protocols were approved by the Safety Division of the RIKEN Institute and were performed in biosafety level 2 rooms in accordance with National Institutes of Health (NIH) Guidelines for Research Involving Recombinant DNA Molecules. The adenoviral vector is based on human adenovirus type 5, and expresses enhanced green fluorescent protein (EGFP) under the control of a neuron-specific promoter synapsin I, as described previously (Tomioka and Rockland, 2006).

Four adult male Sprague Dawley rats (200-250 g body weight) were anesthetized with chloral hydrate $(350 \mathrm{mg} / \mathrm{kg}$ body weight). The virus $\left(0.2-0.3 \mu \mathrm{l}\right.$ of $\left.1.0 \times 10^{12} \mathrm{pfu} / \mathrm{ml}\right)$ was injected stereotaxically into the retrosplenial cortex (coordinates: $4.5 \mathrm{~mm}$ posterior to bregma; 0.5 $\mathrm{mm}$ lateral to the midline; depth, $1.0 \mathrm{~mm}$ below the pial surface). The virus was delivered through a glass capillary with a tip diameter of 15-20 $\mu \mathrm{m}$ by conventional pressure injection. After a survival period of 2 weeks, the animals were deeply reanesthetized with chloral hydrate at the same doses as above and perfusion fixed with a fixative containing $4 \%$ paraformaldehyde, $0.05 \%$ glutaraldehyde, and $15 \%$ $\mathrm{v} / \mathrm{v}$ saturated picric acid in $0.1 \mathrm{M} \mathrm{PB}$. The brains were dissected and cut transversely into $70-\mu \mathrm{m}$-thick serial sections. A specific antibody to EGFP was used in immunofluorescence labeling (Tomioka and Rockland, 2006).

In vitro recording and labeling. Neurons where recorded in vitro from brain slices obtained from 27- to 33-d-old Sprague Dawley rats. The animals were deeply anesthetized using isoflurane (4\%) and decapitated. The brain was quickly removed and placed into ice-cold artificial CSF (ACSF) solution containing the following (in $\mathrm{mm}$ ): $85 \mathrm{NaCl}, 26$ $\mathrm{NaHCO}_{3}, 2.5 \mathrm{KCl}, 1.25 \mathrm{NaH}_{2} \mathrm{PO}_{4}, 0.5 \mathrm{CaCl}_{2}, 7 \mathrm{MgCl}_{2}, 10$ glucose, and 75 sucrose, saturated with $95 \% \mathrm{O}_{2}, 5 \% \mathrm{CO}_{2}$, at $\mathrm{pH}$ 7.3-7.4. The brain was cut horizontally at $300-350 \mu \mathrm{m}$ thickness at a level containing the dorsal hippocampus. The slices were then stored at $\sim 34^{\circ} \mathrm{C}$ for at least $1 \mathrm{~h}$ in a submerged incubation chamber containing sucrose-ACSF, which was gradually exchanged with a recording ACSF with $130 \mathrm{~mm} \mathrm{NaCl}$ and $2 \mathrm{mM}$ $\mathrm{CaCl}_{2}$. Slices were then transferred to a recording chamber and superfused at $\sim 32^{\circ} \mathrm{C}$ at a rate of $1-2 \mathrm{ml} / \mathrm{min}$ with continuously oxygenated recording ACSF.

Analysis of data recorded in vitro. Neurons were visualized with immersion differential interference contrast $40 \times$ and $60 \times$ objectives (Zeiss
Axioskop) and an infrared camera system. Patch pipettes were pulled (Sutter Instruments Co.) from borosilicate glass, and were filled with the following (in $\mathrm{mm}$ ): $126 \mathrm{~K}$-gluconate, $4 \mathrm{KCl}, 4$ ATP-Mg, 0.3 GTP-Na, $10 \mathrm{Na}_{2}$ phosphocreatine, and 10 HEPES, buffered to $\mathrm{pH}$ 7.3. Biocytin $(5 \mathrm{mg})$ was added to a $1 \mathrm{ml}$ aliquot of intracellular solution before recording, and the final osmolarity of the intracellular solution was 280-290 mOsmol. The DC resistance of the electrodes was $4-6 \mathrm{M} \Omega$ when filled with the pipette solution and pressure (60-100 mbar) was applied. Whole-cell patch-clamp recordings were performed with an EPC $9 / 2$ amplifier (HEKA Elektronik) in current-clamp condition. Series resistance and whole-cell capacitance were monitored during the recordings and experiments were discontinued if series resistance increased by $>30 \%$. No correction was made for the junction potential between the pipette and the ACSF and therefore the recorded membrane potential, as calculated post hoc using a junction potential calculator (Barry, 1994), was $16 \mathrm{mV}$ more depolarized than the real membrane potential. The recorded resting membrane potential $\left(V_{\mathrm{rm}}\right)$ was measured in current clamp after obtaining whole-cell configuration. Recordings were filtered at $10 \mathrm{kHz}$ and acquired on-line using a built-in laboratory interface (ITC-16) controlled by Pulse 8.53 software (HEKA). Analysis of intrinsic membrane properties was performed using IGOR Pro 4.0 software (WaveMetrics). The input resistance $\left(R_{\text {in }}\right)$ was calculated from the slope of an $I-V$ plot constructed from steady-state voltage responses to a series of current injections lasting $1000 \mathrm{~ms}$. The latency of the first action potential (AP) evoked by a 1000 -ms-long pulse of rheobase intensity of current was calculated as the time elapsed between the start of the pulse and the peak of the AP. The duration of the AP was measured as the width at half amplitude between the threshold potential and its peak. For the afterhyperpolarization (AHP) parameters, the first action potential was analyzed, after just-suprathreshold current injection. The peak of the AHP was calculated as the amplitude between the threshold potential and the peak of the downward deflection after the action potential. To verify the identity of recorded neurons, cells were filled with biocytin and processed to reveal their dendritic and axonal patterns. After recording, cells were fixed immediately for at least $24 \mathrm{~h}$ by immersion in $4 \%$ paraformaldehyde and $15 \%$ saturated $(\mathrm{v} / \mathrm{v})$ picric acid in $0.1 \mathrm{M} \mathrm{PB}, \mathrm{pH}$ 7.4. Slices were resectioned using a vibratome at $60 \mu \mathrm{m}$ after being embedded in gelatin. Biocytin was then visualized with fluorescent streptavidin conjugated to a fluorophore, and sometimes further processed with diaminobenzidine using the Vector ABC kit (Vector Laboratories) and intensified with osmium tetroxide.

Tissue processing and anatomical analysis of in vivo recorded cells. Immunofluorescence and peroxidase reactions for light and electron microscopy and reconstruction of cells were performed with all necessary controls, as described previously (Klausberger et al., 2005). Neurons were reconstructed using a drawing tube (cells P57b, T126c) or Neurolucida (MicroBrightField) (cell P80a).

Efferent synapses made by COUP-TFII-immunopositive cells were recorded digitally in the electron microscopic analysis. All axons in the plane of the section were monitored in serial sections ensuring random sampling, and postsynaptic targets were identified. Pyramidal cell dendrites were identified by electron-opaque intracellular protein aggregates, emerging spines, and absence of type-I synapses onto their dendritic shafts. Dendritic spines were identified by their specific shape emerging from a dendrite, a single type-I synapse, and the absence of microtubuli. Dendritic shafts receiving type-I synapses and no emerging spines were considered to originate from interneurons. 
The colocalization of COUP-TFII and all other neurochemical markers (supplemental Table 2, available at www.jneurosci.org as supplemental material) was assessed by epifluorescence microscopy in double, triple or quadruple immunoreactions, by photographing under a $40 \times$ objective lens (NA 0.7) cells in all layers from CA1 on both surfaces of the section in random, nonoverlapping fields as described earlier (Jinno and Kosaka, 2002) with all necessary controls.

In vivo recording and labeling. The five recorded and labeled COUPTFII-immunopositive interneurons were obtained from five male Sprague Dawley rats $(250-350 \mathrm{~g})$ anesthetized with urethane $(1.25 \mathrm{~g} / \mathrm{kg}$ body weight), plus supplemental doses of ketamine and xylazine (20 and $2 \mathrm{mg} / \mathrm{kg}$, respectively) as needed; body temperature was maintained with a heating pad. Neuronal activity in the hippocampus was recorded extracellularly with a glass electrode (15-25 M $\Omega$ ) filled with $1.5 \%$ neurobiotin in $0.5 \mathrm{M} \mathrm{NaCl}$, and the local field potential (LFP) was recorded with a nearby second electrode located as close as possible to the CA1 stratum pyramidale. Single-unit activity (sampling rate $20 \mathrm{kHz}$ ) and LFP (sampling rate $1 \mathrm{kHz}$ ) were filtered online between $0.8-5 \mathrm{kHz}$ and $0.3-300 \mathrm{~Hz}$, respectively. The extracellularly recorded cells were individually labeled with neurobiotin using the juxtacellular labeling method, only after data for the firing patterns had been sampled from the unaffected cell. Spike shape and amplitude were monitored during recording and labeling to ensure that the same cell was recorded and labeled. Two to $4 \mathrm{~h}$ after labeling, cardiac perfusion with saline was followed by $\sim 20$ min fixation with a fixative of $4 \%$ paraformaldehyde, $15 \% \mathrm{v} / \mathrm{v}$ saturated picric acid and $0.05 \%$ glutaraldehyde.

Analysis of data recorded in vivo. Local network rhythms studied were theta and ripple oscillations. Unless stated, they were all recorded in stratum pyramidale and considered as the time-frame reference for the spike-timing of the labeled neurons. Theta epochs were detected by calculating the theta $(3-6 \mathrm{~Hz})$ to $\delta(2-3 \mathrm{~Hz})$ ratio in $2 \mathrm{~s}$ windows of the LFP (Csicsvari et al., 1999). Ratio $>4$ in at least three consecutive windows marked theta episodes, and ratio $<2$ in at least three consecutive windows indicated non-theta/non-sharp wave periods; ripple episodes were not included in spike counts for non-theta/non-sharp wave periods. Episodes with intermediate ratio were not included in the analysis. To determine the phase relationship between single-cell activity and theta, the local field potential during theta episodes was filtered between 3 and 6 $\mathrm{Hz}$, and the troughs of the theta oscillations were detected in the filtered signals. For the detection of sharp wave-associated ripples, the LFP was filtered between 90 and $140 \mathrm{~Hz}$, and the power (root mean square amplitude) of the filtered signal was calculated in $10 \mathrm{~ms}$ windows (Csicsvari et al., 1999). The threshold for ripple detection was set to 5 SD above the mean power. Beginning and end of the sharp wave were set where the power crossed $1 \mathrm{SD}$ above the mean power; the peak of the sharp wave was detected by a peak-finding algorithm. To evaluate the firing patterns of a single neuron during sharp waves, these episodes were superimposed by normalization (Klausberger et al., 2003). For all spikes that occurred before the peak of the sharp wave, the time between the beginning and the peak of the sharp wave was normalized into four bins. For all spikes that occurred after the peak of the sharp wave, the time was normalized between the peak and the end of the sharp wave into four additional bins.

Statistics. Unless stated, all tabulated data are presented as the mean $\pm \mathrm{SD}$, and exact Mann-Whitney $U$ test was used for statistical comparisons between populations. The discharge frequency of single cells during three different brain states (theta, sharp wave, and nontheta/non-sharp wave) was calculated by dividing the number of spikes by the summed time of the respective brain state. Theta phase was described and compared using circular statistics (Zar, 1999). Significant differences were accepted at $p<0.05$. For the analysis of molecular co-localization in cell population, data were obtained from 3 animals unless otherwise stated.

\section{Results}

\section{COUP-TFII expression in GABAergic cells}

Neurons immunolabeled for COUP-TFII were broadly scattered in all layers of the dorsal hippocampal CA1 area (Fig. $1 A$ ). Quantification of the cellular distribution established that most
COUP-TFII-expressing cells were concentrated in stratum pyramidale $(35.1 \pm 3.8 \%)$, whereas stratum oriens contained the smallest fraction $(13.8 \pm 6.5 \%, n=746$ cells, 6 animals; supplemental Fig. 1, available at www.jneurosci.org as supplemental material). Protein levels of COUP-TFII varied across cells possibly because different cell populations express the transcription factor at different expression levels (Fig. 1C).

To test whether COUP-TFII-expressing cells were GABAergic, in situ hybridization was performed to detect mRNA for both isoforms of glutamic acid decarboxylase (GAD-65 and GAD-67) and developed by autoradiography in the same sections that had been immunohistochemically reacted for COUP-TFII (Fig. 1). The vast majority of COUP-TFII-expressing cells coexpressed mRNA for GAD $(97.5 \pm 2.3 \%, n=189)$. Furthermore, COUPTFII-expressing cells accounted for a large fraction of the GABAergic cells in the CA1 area $(41.5 \pm 4.7 \%, n=446)$. Similar results were obtained in another set of experiments in which the in situ hybridization signal for GAD was developed by alkaline phosphatase $(n=2$ animals, supplemental Fig. 1 , available at www.jneurosci.org as supplemental material). Most (94.7 \pm $1.5 \%$ ) COUP-TFII-immunopositive cells coexpressed mRNA for GAD $(n=125)$, whereas $49.8 \pm 10.9 \%$ of GABAergic cells $(n=$ 234) were COUP-TFII immunopositive.

The rest of the hippocampus showed comparable results (supplemental Figs. 2, 3, available at www.jneurosci.org as supplemental material). In the CA3 area using the autoradiographic method, $91.3 \pm 7.5 \%$ of the COUP-TFII-expressing cells were GAD positive $(n=140)$, and COUP-TFII-expressing cells comprised $30.3 \pm 6.4 \%$ of the detected GAD-positive cells $(n=456)$. In the dentate gyrus $87.1 \pm 6.4 \%$ of the COUP-TFII-immunopositive cells expressed mRNA for $\mathrm{GAD}(n=187)$, and $36.7 \pm 2.8 \%$ of the GAD-expressing cells contained COUP-TFII $(n=443$; autoradiography). In addition, a gradient of expression was detected in pyramidal cells of the hippocampus in the septotemporal axis, such that COUP-TFII was strongly expressed in ventrotemporal regions, whereas in dorsoseptal territories COUP-TFII expression was gradually declining to nondetectable level in the dorsal hippocampus (supplemental Fig. 2, available at www.jneurosci.org as supplemental material).

In other brain areas outside the hippocampus, COUP-TFII was intensely expressed in the neocortex, the thalamic reticular nucleus, amygdala and hypothalamus (supplemental Fig. 3, available at www.jneurosci.org as supplemental material). In addition, similar to the expression pattern of COUP-TFI (Armentano et al., 2007), COUP-TFII was also expressed in a gradient across the brain, increasing in intensity from dorsal to ventral and from rostral to caudal (supplemental Fig. 2, available at www. jneurosci.org as supplemental material).

\section{Neurochemical characterization of GABAergic neurons expressing COUP-TFII}

To identify the COUP-TFII-expressing GABAergic neurons, fluorescent immunocytochemical reactions for multiple molecular cell markers were performed in the dorsal CA1 area of the hippocampus in perfusion-fixed rat brain tissue (Figs. 2-4). Different $\mathrm{Ca}^{2+}$-binding proteins are present in large, nonoverlapping GABAergic populations in the hippocampus (Freund and Buzsáki, 1996). In quadruple reactions for COUP-TFII, PV, CB, and CR; COUP-TFII and PV were expressed in completely nonoverlapping populations ( $n=630$ cells), even in stratum pyramidale where both markers were most densely expressed (Fig. $2 B$; supplemental Table 2 , available at www.jneurosci.org as supplemental material). Remarkably, the postnatal maturation PV- 

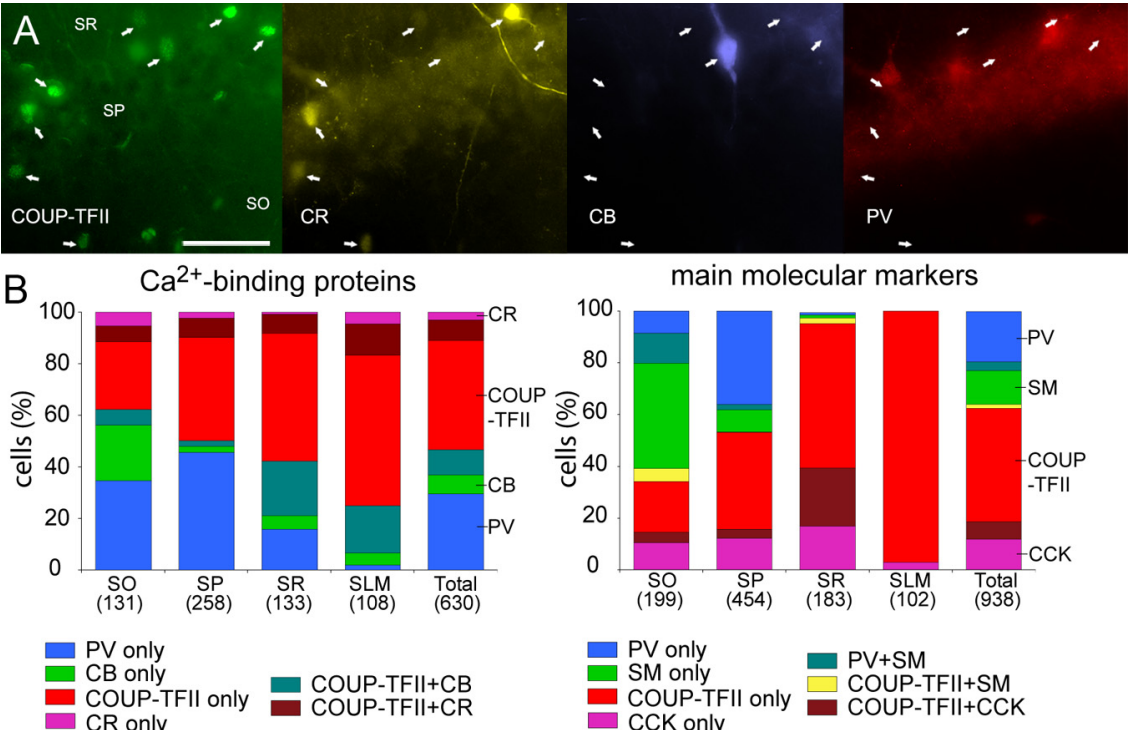

main molecular markers

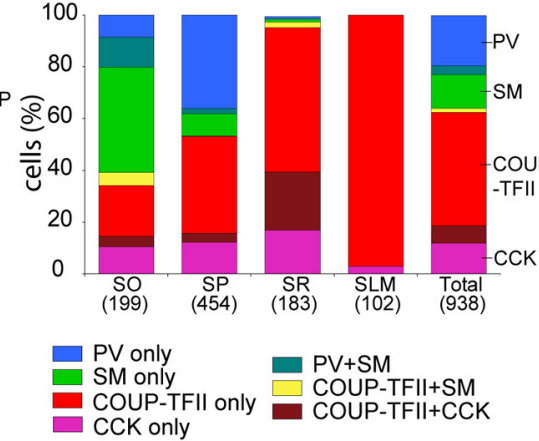

Figure 2. Immunohistochemical characterization of COUP-TFIl-expressing neuronal populations. $\boldsymbol{A}$, Fluorescent micrographs show the relationship of COUP-TFIl and $\mathrm{Ca}^{2+}$-binding protein-immunopositive cells. Note overlap between immunoreactivity for COUP-TFIl and CB or CR, but not PV. Arrows indicate COUP-TFIl-immunopositive neuronal nuclei. $B$, Quantification of colocalization for COUP-TFIl and $\mathrm{Ca}^{2+}$-binding proteins, or COUP-TFIl and neuropeptides and parvalbumin in the CA1 area. The number of counted cells is shown in parentheses. Scale bar, $50 \mu \mathrm{m}$.
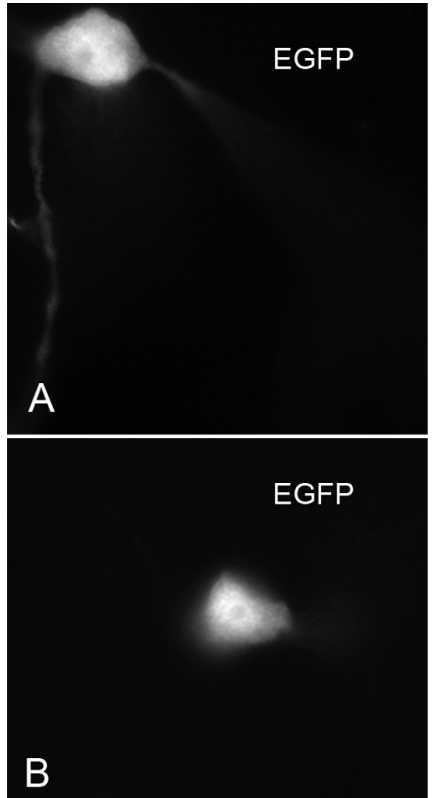
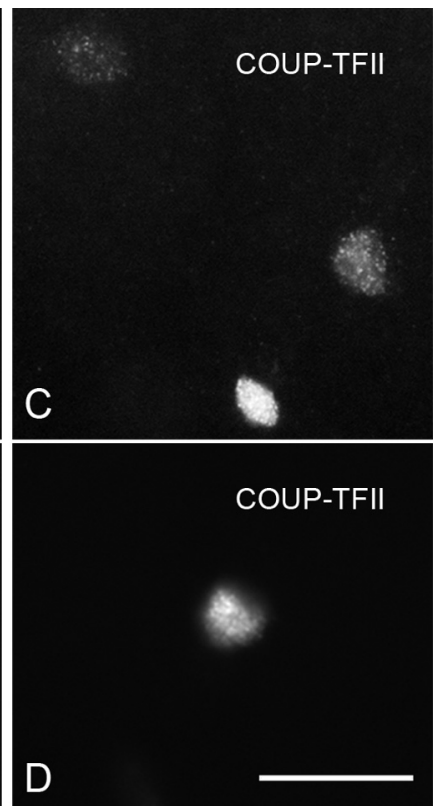

Figure 3. Immunoreactivity for COUP-TFll in radiatum-retrohippocampal long-range projection cells. $\boldsymbol{A}, \boldsymbol{B}$, Fluorescent micrographs of retrogradely labeled cells projecting to the retrosplenial cortex visualized by an antibody to EGFP. Cells are labeled by retrograde transport of a recombinant adenovirus vector injected into the retrosplenial cortex. $C, D$, The nuclei of the projection cells and some nearby neurons are immunopositive for COUP-TFIl to varying degrees. Scale bar, $20 \mu \mathrm{m}$.

immunopositive cells rely on another transcription factor, the homeoprotein Otx2, which they may gain from the extracellular space, as PV-expressing cortical interneurons do not appear to express mRNA for Otx2 (Sugiyama et al., 2008). In contrast to PV-immunopositive neurons, both the CR and CB populations coexpressed COUP-TFII to a large extent (CR cells, $79.2 \pm$ $10.3 \%, n=254$; CB cells, $56.4 \pm 12.2 \% ; n=187 ; n=6$ animals, supplemental Table 2, available at www.jneurosci.org as supplemental material).

In both the neocortex and hippocampus major GABAergic populations are identified by the expression of PV, SM and CCK (Freund and Buzsáki, 1996; Kawaguchi and Kondo, 2002). Quadruple immunoreactions for COUP-TFII, SM, $\mathrm{PV}$ and CCK showed that interneurons immunopositive for COUP-TFII formed the largest population, nearly threefold larger than any other group across all layers (Fig. $2 B$ ). In addition, the expression of COUP-TFII showed only a minor overlap with the other molecular cell population markers. Thus, COUP-TFII is likely to demarcate a largely distinct cell population (coexpressing cells: PV, 0\%; SM, $3.0 \pm 1.4 \%$; CCK, $12.7 \pm 3.4 \%, n=490)$. Interestingly, in the CA1 area the coexpression of COUP-TFII and CCK varied across layers. The highest levels were in stratum radiatum, where nearly one-third of cells $(30.4 \pm 6.9 \%$, supplemental Table 2, available at www.jneurosci.org as supplemental material) immunopositive for COUP-TFII $(n=143)$ coexpressed CCK. In addition, no immunoreactivity for COUP-TFII was detected in the very small population of local cholinergic cells in the CA1 area ( $n=12$ cells, 2 animals).

Recently, diverse hippocampal GABAergic long-range projection cells have been described (Jinno et al., 2007). Some of the projection cells located in deep stratum radiatum were immunonegative for all molecules tested (see cells T74b and T100c in Jinno et al., 2007), including the main population markers for GABAergic neurons, such as PV, SM and CCK. These neurons projected caudally from the CA1 area, reaching the retrosplenial cortex, and were denominated as radiatum-retrohippocampal cells. To test them for the expression of COUP-TFII, we injected a recombinant adenoviral vector as a GFP-based sensitive retrograde tracer (Tomioka and Rockland, 2006) in the retrosplenial cortex and immunoreacted labeled nonpyramidal projection cell somata for the expression of COUP-TFII (Fig. 3). The injections retrogradely labeled a small number of nonpyramidal cells located in strata oriens and radiatum in the CA1 area, consistent with previous findings (Miyashita and Rockland, 2007). The majority of radiatum-retrohippocampal cells projecting to the retrosplenial cortex were immunopositive for COUP-TFII (79.5 $\pm 23.2 \%, n=31)$; the immunoreactivity of the remaining was inconclusive $(n=5)$. Thus, COUP-TFII is a molecular marker for the radiatum-retrohippocampal GABAergic cell type with otherwise largely unknown neurochemical composition.

Given the abundance of COUP-TFII-expressing neurons, we tried to characterize further the cell types expressing this nuclear receptor in additional colocalization experiments. Interneuronselective cells constitute at least three different cell types based on their connectivity and neurochemical characteristics (Freund and Buzsáki, 1996). They are present in all layers of the CA1 area and some layers of the neocortex (Caputi et al., 2009) and have been demonstrated to express CR (Gulyás et al., 1996) and/or vasoactive intestinal polypeptide (VIP) (Acsády et al., 1996) and/or enkephalin (Blasco-Ibáñez et al., 1998). In quadruple immunoreactions, testing for the molecules COUP-TFII, CR, VIP and enkephalin (Fig. 4A), the large majority of putative interneuron-selective cells expressed COUP-TFII (84.2 $\pm 9.4 \%$, 
$n=285)$, with little variability across layers (Fig. $4 B$; supplemental Table 2, available at www.jneurosci.org as supplemental material). On the other hand, putative interneuron-selective cells comprised only about half of the total population of COUP-TFII-expressing cells ( $49.8 \pm 4.8 \%$, $n=477)$.

Because the pyramidal cell layer was rich in COUP-TFII-immunopositive neurons, where a large population of neuronal nitric oxide synthase (nNOS)- and NPY-expressing interneurons described as ivy cells were reported (Fuentealba et al., 2008a), we tested the coexistence of COUP-TFII, nNOS and NPY in triple immunoreactions. The majority of nNOS and NPY double-immunopositive cells ( $58.8 \pm 10.1 \%, n=183)$, the putative ivy cells, expressed COUP-TFII in their nuclei, which represented approximately half of the COUP-TFII-immunopositive cells in stratum pyramidale $(47.9 \pm 4.3 \%, n=223)$ (Fig. $4 B$; supplemental Table 2, available at www. jneurosci.org as supplemental material).

High levels of nuclear COUP-TFII were also found in stratum lacunosummoleculare, where putative interneuron-selective cells account for half of the COUP-TFII-immunopositive neuronal population. In this layer, neurogliaform cells were reported expressing a high level of $\alpha$-actinin-2 in their somata (Price et al., 2005). Double immunoreactions for COUP-TFII and $\alpha$-actinin-2 showed that all $\alpha$-actinin-2-expressing cells $(n=$ 50 ), the putative neurogliaform cells, were immunopositive for COUP-TFII accounting for approximately half $(45.4 \pm 4.8 \%)$ of the COUP-TFII-immunopositive interneurons $(n=104)$ in stratum lacunosum-moleculare (Fig. 4B; supplemental Table 2, available at www.jneurosci.org as supplemental material).

These results show that COUP-TFII is expressed by several types of interneuron, which together are more numerous than any of the major identified GABAergic cell types in the dorsal hippocampus. Furthermore, COUP-TFII expression is restricted to a few, largely nonoverlapping populations of GABAergic interneuron types, the interneuron-selective cells (CR, VIP, enkephalin), ivy cells (nNOS, NPY), putative neurogliaform cells ( $\alpha$-actinin-2), radiatum-retrohippocampal projection cells and minor subpopulations of CCK- and CB-expressing interneurons.

\section{COUP-TFII and reelin in neurogliaform cells}

Putative neurogliaform cells expressing high level of $\alpha$-actinin-2 in the soma were tested further to establish their neurochemical profile. In stratum lacunosum-moleculare all cells immunopositive for $\alpha$-actinin-2 $(n=50)$ coexpressed COUP-TFII and a high level of the $\alpha 1$ subunit of the $\mathrm{GABA}_{\mathrm{A}}$ receptor in the somatodendritic membrane $\left(\mathrm{GABA}_{\mathrm{A}}-\alpha 1, n=48\right)$, and the majority was also immunopositive for reelin $(n=45)$ (Fig. $5 A)$. In addition, nearly half of the $\alpha$-actinin-2-expressing cells were colabeled for low levels of nNOS $(44.0 \pm 2.7 \%, n=50)$ or NPY $(52.1 \pm 1.8 \%, n=$ $48)$, and virtually none coexpressed the $\mathrm{Ca}^{2+}$-binding protein CR (Fig. 5A). These results strongly suggest that the molecular profile of neurogliaform cells includes $\alpha$-actinin-2 as well as COUP-TFII, $\mathrm{GABA}_{\mathrm{A}}-\alpha 1$ and reelin.
To test such a prediction directly, whole-cell patch-clamp recordings with biocytin-labeling were performed in slices of adult rat hippocampus to visualize the processes of the cells. Neurogliaform cells were identified by their round somata located in close proximity to the fissure, their short, aspiny and profusely branched dendrites, and their dense axon, coaligned to the entorhinal input region, i.e., stratum lacunosum-moleculare in the CA1 area and stratum moleculare in the dentate gyrus (Price et al., 2005). From 17 cells recorded in stratum lacunosummoleculare, 13 were identified as neurogliaform cells (supplemental Table 3, available at www.jneurosci.org as supplemental material). When neurogliaform cells were stimulated with depolarizing current pulses, characteristic delayed, stuttering and adapting firing patterns were seen (Fig. $5 B$ ), as previously described (Price et al., 2005). Interestingly, during depolarized states neurogliaform cells exhibited small-amplitude, subthreshold membrane potential oscillations in the gamma-band range $(30-60 \mathrm{~Hz})$ (Fig. 5B), consistent with results found in unidentified interneurons in strata radiatum and lacunosum-moleculare recorded in slices (Bourdeau et al., 2007). Such subthreshold oscillations seemed to be voltage-dependent and were absent at resting membrane potential.

Immunocytochemical reactions of the visualized and anatomically identified neurogliaform cells confirmed the results found in perfusion-fixed brain tissue, for all tested neurogliaform cells were immunopositive for COUP-TFII $(n=6), \alpha$-actinin-2 $(n=5), \mathrm{GABA}_{\mathrm{A}}-\alpha 1(n=9)$ and/or reelin $(n=5)$ (Fig. $\left.5 C\right)$. These results confirmed $\alpha$-actinin-2 as a marker of neurogliaform cells in stratum lacunosum-moleculare, and also extended their characterization by the demonstration of COUP-TFII, $\mathrm{GABA}_{\mathrm{A}}-\alpha 1$ and reelin immunoreactivities.

The above results suggest that the majority of neurogliaform and ivy cells share COUP-TFII expression. To compare neurogliaform cells and the related ivy cells for the newly identified reelin expression, we ran a quadruple immunoreaction on three additional rats using antibodies to nNOS, NPY and reelin and also 
A
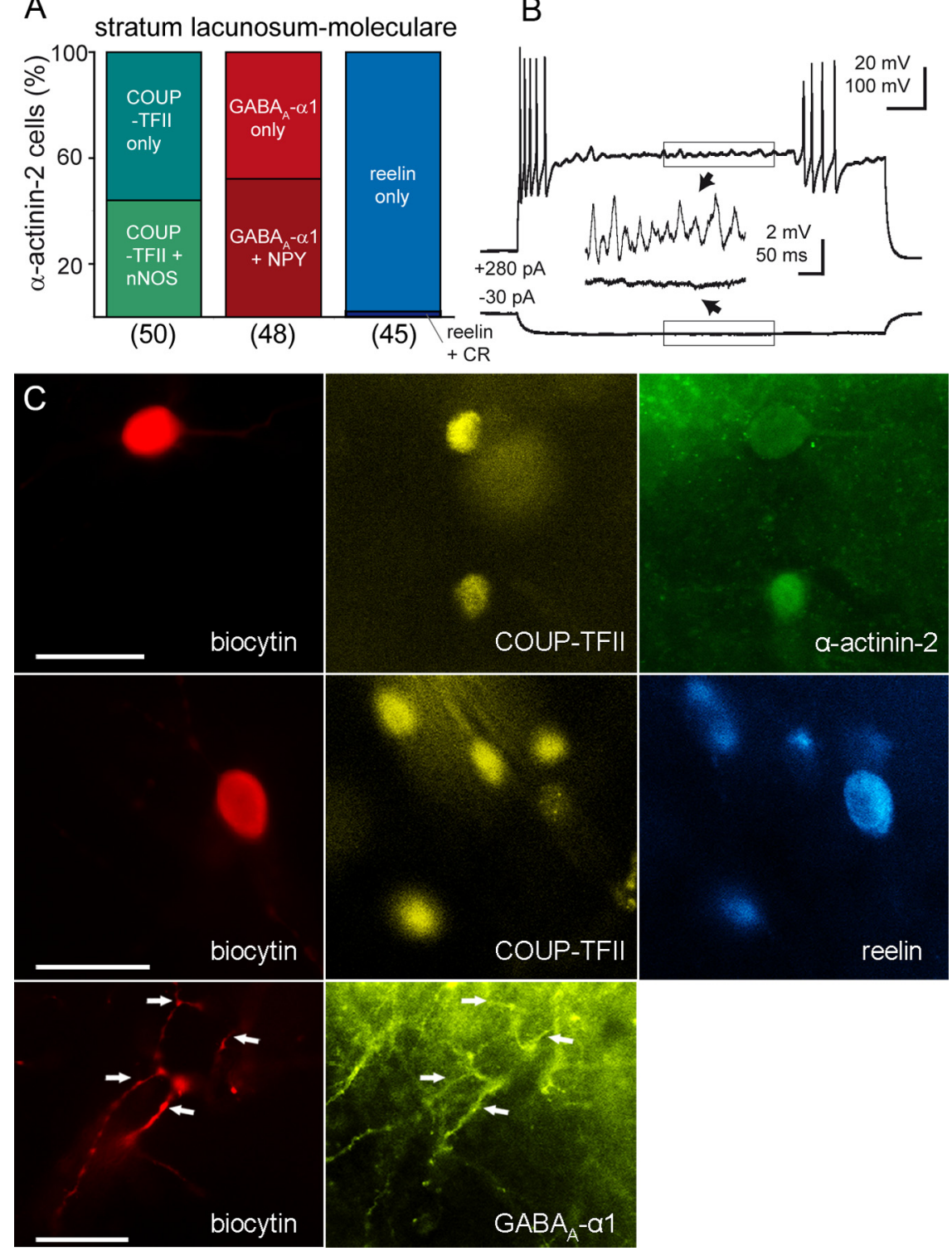

Figure 5. Expression of COUP-TFIl and reelin in neurogliaform cells. $A$, Coexpression of signaling molecules in putative neurogliaform cells revealed by $\alpha$-actinin-2 immunolabeling in stratum lacunosum-moleculare tested by triple labeling of perfused brain tissue. All putative neurogliaform cells coexpress COUP-TFII, $\mathrm{GABA}_{A}-\alpha 1$ and reelin, whereas approximately half express $n N O S$ or NPY. The number of counted cells is shown in parentheses. $\boldsymbol{B}$, An in vitro whole cell recorded neurogliaform cell displays the characteristic stuttering firing pattern upon a depolarizing current pulse. Inset, subthreshold, voltage-dependent membrane potential oscillations in the gamma range $(30-60 \mathrm{~Hz})$ between discharge periods. C, Fluorescent micrographs show immunolabeling for COUP-TFIl, $\alpha$-actinin-2, reelin and $\mathrm{GABA}_{\mathrm{A}}-\alpha 1$ (dendrites) in three identified neurogliaform cells recorded and biocytinfilled in vitro. Other nonrecorded COUP-TFII-immunopositive cells also coexpress $\alpha$-actinin-2 and reelin. Arrows indicate dendrites of a neurogliaform cell. Scale bars, $20 \mu \mathrm{m}$.

somatostatin because of its presence in several interneuron types that express NPY (supplemental Table 2, available at www. jneurosci.org as supplemental material). To provide the highest possible estimate of putative ivy cells, we counted all nNOS and/or NPY-immunopositive cells in strata oriens, radiatum and pyramidale, where they have been reported. Of the 351 cells analyzed that were immunopositive for nNOS and/or NPY in these layers, only $12.4 \%$ were immunopositive for reelin. Of these 43 cells, $73 \%$ were located in stratum radiatum, mostly close to the border with stratum lacunosum-moleculare, where neurogliaform cells are present. Therefore, the majority of reelin-immunopositive cells that express NPY and/or nNOS in these layers may be neurogliaform cells. In stratum pyramidale where ivy cells are most numerous, only $5.3 \%$ of NPY and/or nNOS-immunopositive cells that were negative for somatostatin $(n=181)$, the putative ivy cells, were immunopositive for reelin. Furthermore, these values are likely to be an overestimation for ivy cells, as in this calculation we considered putative ivy cells any cell expressing nNOS and/or NPY. Therefore, we conclude that ivy cells, in general, do not express reelin, which is in contrast to neurogliaform cells.

The same reaction also revealed that approximately one third of all reelinimmunopositive cells were immunoreactive for somatostatin, but not nNOS or NPY, and approximately half of all reelin imunopositive cells were in stratum oriens. A prominent cell type in stratum oriens is the O-LM cell, which expresses somatostatin but not NPY. Because $92 \%$ of somatostatin-immunopositive cells express reelin in stratum oriens, and O-LM cells are likely to be the largest population of somatostatin-expressing cell type in stratum oriens, we conclude that most, and may be all, O-LM cells express reelin. The other significant interneuron population expressing reelin includes cells immunopositive for both somatostatin and NPY and are most frequent in stratum oriens ( $85 \%$ of such cells in all layers) and could be projection cells (Jinno et al., 2007), but this remains to be tested directly. Bistratified cells which in addition to somatostatin and NPY also express parvalbumin are unlikely to express reelin, as little overlap was found between reelin and parvalbumin immunoreactivities (data not shown).

\section{Axodendritic distribution and spike-timing of COUP-TFII-expressing cells during network oscillations in vivo}

To determine the temporal patterns of activity and the full extent of axodendritic distributions of COUP-TFII-expressing cells, we recorded extracellularly and labeled single interneurons in the CA1 area of anesthetized rats during different brain states. Among other interneurons reported previously, five COUP-TFII-immunopositive cells were labeled with somata located in the deep layers of CA1; two cells were in stratum lacunosum-moleculare (P33b, T126c) and three others in deep stratum radiatum (P57b, P75b, and $\mathrm{P} 80 \mathrm{a})$. Their spike-timing was recorded during theta $(4.1 \pm 0.5 \mathrm{~Hz})$ and sharp waveassociated ripple $(117.7 \pm 15.2 \mathrm{~Hz})$ oscillations. An additional COUP-TFII-immunopositive interneuron in stratum radiatum has been reported earlier (Fuentealba et al., 2008a).

\section{Neurogliaform cells in stratum lacunosum-moleculare}

Two cells recorded and labeled in stratum lacunosum-moleculare were identified as neurogliaform cells (P33b, T126c) based 

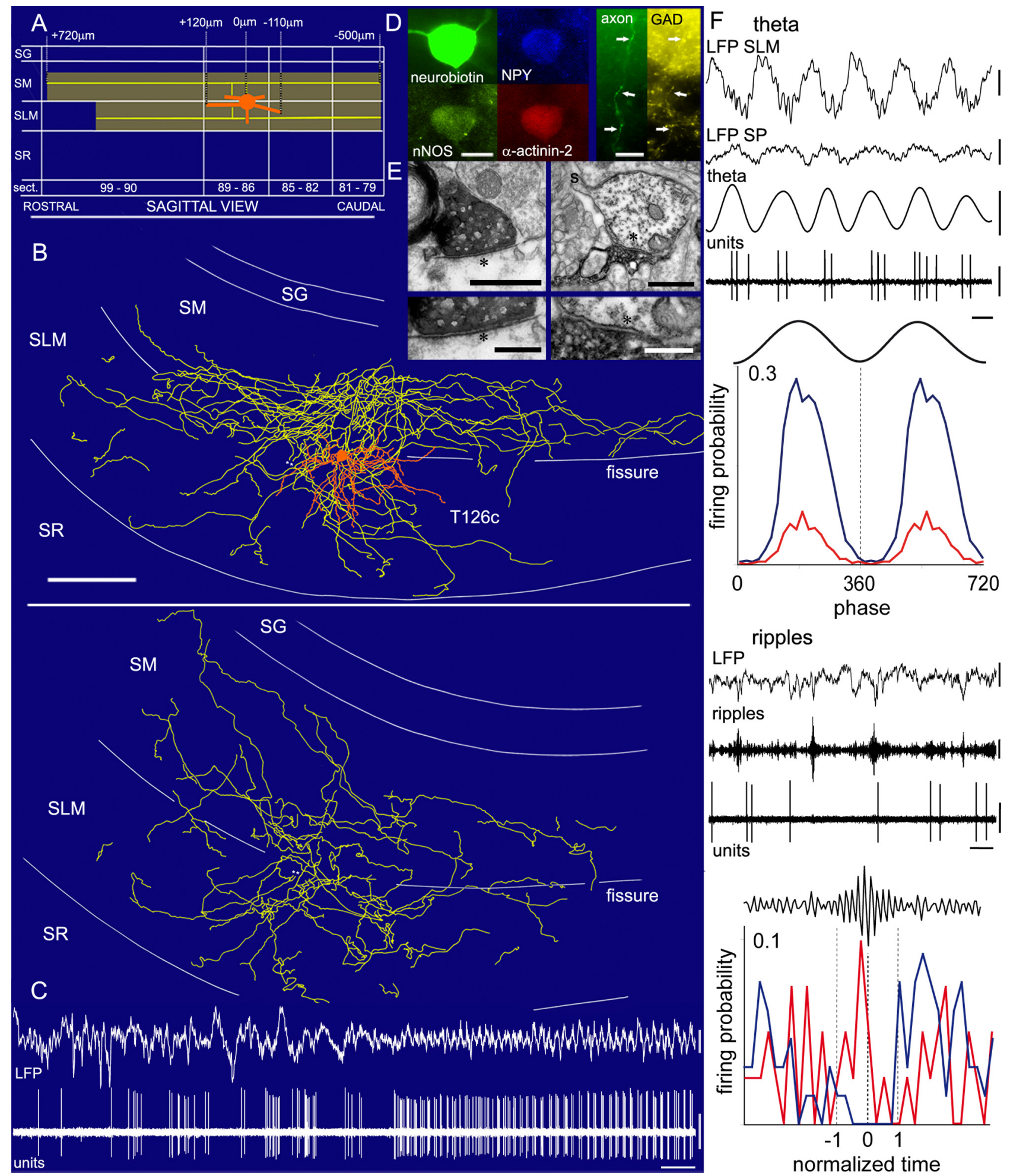

Figure 6. Axodendritic distribution and molecular profile of neurogliaform cells recorded in vivo. A, Rostrocaudal projection of the axonal arborization of a neurogliaform cell (T126c) labeled by neurobiotin. Note the $1.2 \mathrm{~mm}$ extension and layer restriction of the axon, which innervates both the dentate gyrus (SM) and the CA1 area [stratum lacunosum-moleculare (SLM)]. $\boldsymbol{B}$, Partial reconstruction of the neurogliaform cell (T126c). Top: soma and dendrites complete (orange), axonal arborization (yellow) only from 5 coronal sections ( $60 \mu \mathrm{m}$ ). Note the dendrites biased to stratum lacunosum-moleculare (SLM). Bottom: axonal arborization from another 5 sections located caudally. $C$, In vivo firing pattern of the cell during the transition from slow-wave oscillations to theta waves. D, Another recorded and neurobiotin-labeled neurogliaform cell (P33b) immunopositive for NPY, nNOS and $\alpha$-actinin-2 in the soma, and GAD-65 in the axon. $\boldsymbol{E}$, Synaptic targets of neurogliaform cells identified by electron microscopy. Horseradish peroxidase product-labeled boutons (left, T126c; right, P33b) making type-Ill synaptic junctions with dendritic shafts of pyramidal cells in stratum lacunosum-moleculare (SLM). Note a spine (right, s) emerging from one of the dendrites. The synaptic cleft is shown magnified in bottom panels. $\boldsymbol{F}$, Firing patterns of identified neurogliaform cells during spontaneous network oscillations. Example traces of the local field potential (LFP, $0.3-300 \mathrm{~Hz}$ ), theta (stratum pyramidale, filtered LFP, 3-6 Hz) or ripple (filtered LFP, $90-140 \mathrm{~Hz}$ ) oscillations and spike train (units, $0.8-5 \mathrm{kHz}$ ) of a neurogliaform cell (T126c) during theta waves (theta, top) and ripple episodes (ripples, bottom). Note phase reversal and amplitude difference between LFPs recorded from stratum pyramidale (SP) and stratum lacunosum moleculare (SLM). Theta phase (top) and ripple episode (bottom) firing probability histograms for two neurogliaform cells ( $\mathrm{T} 126 \mathrm{c}$, blue; $\mathrm{P} 33 \mathrm{~b}$, red). The same data are repeated in two cycles for theta histograms to indicate oscillations. The trough of the extracellularly (Figure legend continues.) 
Table 1. Molecular expression profiles of COUP-TFII-expressing interneuron types recorded in vivo

\begin{tabular}{|c|c|c|c|c|c|}
\hline \multirow[b]{2}{*}{ Immunoreaction } & \multicolumn{5}{|l|}{ Cell/type } \\
\hline & $\begin{array}{l}\text { T126c } \\
\text { Neurogliaform }\end{array}$ & $\begin{array}{l}\text { P33b } \\
\text { Neurogliaform }\end{array}$ & $\begin{array}{l}\text { P57b } \\
\text { basket }\end{array}$ & $\begin{array}{l}\text { P75b } \\
\text { basket }\end{array}$ & $\begin{array}{l}\text { P80a } \\
\text { RADI }\end{array}$ \\
\hline COUP-TFII & nt & + & + & + & + \\
\hline$\alpha$-Actinin-2 & + & + & nt & nt & $\mathrm{nt}$ \\
\hline GABA- $\alpha 1$ & + & + & $\mathrm{nt}$ & nt & $\mathrm{nt}$ \\
\hline GAD & + & + & nt & nt & nt \\
\hline MOR & - & nt & nt & nt & nt \\
\hline nNOS & - & + & - & nt & nt \\
\hline NPY & - & + & $\mathrm{nt}$ & nt & $\mathrm{nt}$ \\
\hline SM & - & nt & nt & nt & nt \\
\hline CCK & - & nt & - & + & - \\
\hline vGluT3 & - & nt & $\mathrm{nt}$ & nt & - \\
\hline$C R$ & nt & $\mathrm{nt}$ & - & $\mathrm{nt}$ & nt \\
\hline CB1 & nt & $\mathrm{nt}$ & $\mathrm{nt}$ & + & + \\
\hline VIP & nt & nt & - & - & nt \\
\hline NK1 & nt & nt & nt & nt & - \\
\hline$M 2 R$ & nt & nt & - & nt & nt \\
\hline$C B$ & nt & nt & $\mathrm{nt}$ & nt & + \\
\hline РРТВ & nt & nt & $\mathrm{nt}$ & nt & + \\
\hline
\end{tabular}

GAD, Glutamic acid decarboxylase; M2R, muscarinic receptor 2; MOR, $\mu$ opioid receptor; NK1, neurokinin receptor 1; nt, non-tested; vGluT3, vesicular glutamate transporter 3 .

on their axodendritic distributions (Fig. 6). Consistent with the results found in vitro, the round somata of neurogliaform cells were located very close to the fissure and their dendrites were short and branched copiously, and were fully contained within the dense axonal cloud (Fig. 6A,B). Overall, their axodendritic structure was consistent with neurogliaform cells reported in the neocortex (Simon et al., 2005; Oláh et al., 2009), particularly in layer I (Hestrin and Armstrong, 1996), which in the hippocampus corresponds to stratum lacunosum-moleculare. The axon was very fine, dense, and restricted to the entorhinal input region, i.e., stratum lacunosum-moleculare and stratum moleculare, wandering freely across the hippocampal fissure. The axon spanned $\sim 0.5 \mathrm{~mm}$ in the mediolateral axis and it was longer in the septotemporal axis, reaching approximately $1.2 \mathrm{~mm}$ (Fig. $6 A, B)$. Both identified neurogliaform cells were tested for the expression of various molecular markers involved in intercellular signaling (Table 1). They were both immunopositive for $\alpha$-actinin- 2 and the $\mathrm{GABA}_{\mathrm{A}}$ receptor $\alpha 1$ subunit in their somata, confirming the results found in vitro and in perfusion-fixed brain tissue (Fig. 6D). Both cells were also immunopositive for GAD in their axons.

Random samples of boutons from both neurogliaform cells were evaluated by electron microscopy to identify their postsynaptic targets ( $n=26 ; 10$ for T126c and 16 for P33b). Because of suboptimal tissue preservation we could not establish whether all the boutons made synaptic junctions. Of those that did, more than half $(58 \%)$ made synapses onto small dendritic shafts of pyramidal cells $(n=15)$, yet $15 \%$ of targets were spines $(n=4)$. Two boutons from one cell (T126c) made synapses on granule cell dendrites in stratum moleculare, which is probably a common feature of these cells since their axon freely crosses the fissure into the

(Figure legend continued.) recorded oscillations in stratum pyramidale are at $0^{\circ}, 360^{\circ}$ and $720^{\circ}$; bin size is $18^{\circ}$. The onset, highest amplitude and end of normalized ripple episodes are marked as $-1,0,1$, respectively (dotted lines). SG, stratum granulosum; SM, stratum moleculare; $S R$, stratum radiatum. Scale bars: $\boldsymbol{B}, 100 \mu \mathrm{m} ; \boldsymbol{C}, \mathrm{LFP} 0.5 \mathrm{mV}$, units $0.5 \mathrm{mV}$, horizontal $1 \mathrm{~s} ; \boldsymbol{D}$, $10 \mu \mathrm{m} ; \boldsymbol{E}$, upper row, $0.5 \mu \mathrm{m}$; lower row, $0.2 \mu \mathrm{m} ; \boldsymbol{F}$, LFP $1 \mathrm{mV}$, filtered theta $0.5 \mathrm{mV}$, ripples 0.1 $\mathrm{mV}$, units $0.5 \mathrm{mV}$, horizontal, theta $100 \mathrm{~ms}$, ripples $500 \mathrm{~ms}$.
Table 2. Discharge frequencies and phases of identified COUP-TFII-expressing cells during network oscillations

\begin{tabular}{|c|c|c|c|c|c|}
\hline \multirow[b]{2}{*}{ Cell } & \multirow[b]{2}{*}{ Type } & \multicolumn{3}{|c|}{ Discharge frequency (Hz) } & \multirow{2}{*}{$\begin{array}{l}\text { Mean phase }\left(^{\circ}\right) \pm \text { angular } \\
\text { deviation } \\
\text { Theta }\end{array}$} \\
\hline & & Theta & Ripples & $n-t / n-r$ & \\
\hline $\mathrm{T} 126 \mathrm{c}$ & Neurogliaform & 10 & 0.4 & 1.5 & $199 \pm 44$ \\
\hline P33b & Neurogliaform & 2 & 4.2 & 3.8 & $192 \pm 41$ \\
\hline P57b & Basket & 3.8 & 1.7 & & $198 \pm 52$ \\
\hline P75b & Basket & 8 & 4.4 & & $198 \pm 55$ \\
\hline P80a & RADI & 6.6 & 7 & 4.4 & $222 \pm 65$ \\
\hline
\end{tabular}

$\mathrm{n}$-t/n-r, Non-theta/non-ripple episodes.

dentate gyrus (Fig. 6 B). For $19 \%$ of the boutons $(n=2$ for P33b, 3 for T126c) it was not possible to establish the origin of the postsynaptic target clearly, other than as a dendritic shaft.

Both cells discharged at relatively low frequencies (Table 2), yet exhibited clear phase preferences during hippocampal rhythms (Fig. 6F). During theta oscillations, neurogliaform cells fired just after the peak of the cycles recorded extracellularly in stratum pyramidale with a second electrode (Table 2), coincident with the presumed synaptic volley from the entorhinal cortex (Buzsáki, 2002). The firing of both cells appeared to be phasecoupled to the local gamma frequency field potential (supplemental Fig. 4, available at www.jneurosci.org as supplemental material). During ripple oscillations one neurogliaform cell appeared to decrease its firing rate $(\mathrm{T} 126 \mathrm{c})$, whereas for the other one, this remained unaltered on average (P33b) (Fig. 6F); however during most episodes both cells remained silent (P33b, 70\%; T126c, 97\%).

\section{Basket cells in stratum radiatum}

Based on their axonal patterns, two cells recorded in stratum radiatum (P57b, P75b) were identified as basket cells. The elongated soma of one of the basket cells (P57b), located deep in stratum radiatum, at the border with stratum lacunosummoleculare, was horizontally oriented. The dendrites were thin and long, mostly parallel to the border and extended almost exclusively in stratum lacunosum-moleculare. One dendrite was radially oriented and reached stratum oriens where it branched copiously (Fig. $7 A, B$ ). The axon was fine and had few boutons in stratum radiatum, and branched extensively within stratum pyramidale. The axon extended $1.1 \mathrm{~mm}$ in both the mediolateral and septotemporal axes (Fig. 7 A,B). The soma of cell P57b was tested for the expression of various molecules (Table 1) but was found to be immunopositive only for COUP-TFII (Fig. 7C). Unexpectedly, this cell did not coexpress the neuropeptide CCK, as it has been previously shown for basket cells in stratum radiatum (Katona et al., 1999; Pawelzik et al., 2002). The soma was surrounded by enkephalin-immunopositive terminals (Fig. 7C).

The other basket cell (P75b) was also immunopositive for COUP-TFII and had a dense, restricted innervation of stratum pyramidale (data not shown) and was immunopositive for CCK in the soma and cannabinoid receptor 1 (CB1) in the axon (Table 1). During theta oscillations, both cells fired just after the peak of the cycles recorded extracellularly in stratum pyramidale with a second electrode (Fig. 7D; Table 2). During ripple oscillations, neither of the basket cells altered its firing rate and remained inactive during the majority of ripple episodes (P57b, 73\%; P75b, 88\%).

\section{Radiatum- and dentate-innervating interneuron}

Interneuron P80a had a highly selective axonal projection to both stratum radiatum of the CA1 area and surprisingly, to the inner third of stratum moleculare and stratum granulosum of the den- 
tate gyrus, practically avoiding stratum lacunosum-moleculare and the external stratum moleculare (Fig. 8A,B). The cell body was located in deep stratum radiatum at the border with stratum lacunosummoleculare. Most dendrites were relatively short, restricted to stratum lacunosummoleculare, suggesting that this cell gets its main glutamatergic inputs from the entorhinal cortex via the perforant path and/or the thalamus. The axon, having abundant large varicosities, branched profusely in both areas spanning $1.1 \mathrm{~mm}$ in the mediolateral axis and $1.2 \mathrm{~mm}$ in the septotemporal axis.

Multiple single axonal branches crossed radially both strata radiatum and granulosum, suggesting extensive, parallel innervation of apical dendrites of pyramidal cells and both the main dendrites and somata of granule cells (supplemental Fig. 5, available at www.jneurosci.org as supplemental material). Electron microscopic evaluation of random samples of boutons identified the postsynaptic targets (Fig. $8 B$; supplemental Fig. 5, available at www. jneurosci.org as supplemental material). In the dentate gyrus, nearly half of the sampled boutons $(n=15)$ made synapses onto somata of granule cells ( $48 \%$ ), whereas the remaining boutons targeted large $(>1$ $\mu \mathrm{m})$ and small dendritic shafts of granule cells (26\% and 26\%, respectively). Interestingly, in the CA1 area the targets were mostly large $(>1 \mu \mathrm{m})$ dendritic shafts $(n=12)$, which included apical dendrites of pyramidal cells $(75 \%)$ as well as dendrites of interneurons (25\%).

The soma of the radiatum- and dentateinnervating (RADI) cell was immunopositive for COUP-TFII, the $\mathrm{Ca}^{2+}$-binding protein $\mathrm{CB}$, and the neuropeptide precursor preprotachykinin B (PPTB) (Fig. 8C). Interestingly, the axon was immunopositive for CB1 receptor; however, CCK could not be detected in the axon or the soma (Table 1).

Because interneurons with features of the RADI cell have not been reported previously, we attempted to establish their relative abundance by studying the colocalization of the molecules COUP-TFII, CB and PPTB in a triple fluorescent immunocytochemical reaction. A large proportion $(63.2 \pm 6.7 \%)$ of the tested cells coexpressing the three markers $(n=66)$ was located in deep stratum radiatum, similar to the identified RADI cell. The rest were distributed in strata pyramidale and lacunosummoleculare (supplemental Table 2, available at www.jneurosci. org as supplemental material). In all layers, cells coexpressing the three markers accounted for a large fraction of either the CB- or PPTB-expressing populations in stratum radiatum $(72.3 \pm$ $16.6 \%, n=78$ and $53.5 \pm 4.5 \%, n=139$; for CB- and PPTBexpressing cells, respectively), in contrast to what has been reported in the neocortex (Kaneko et al., 1998). Furthermore, we
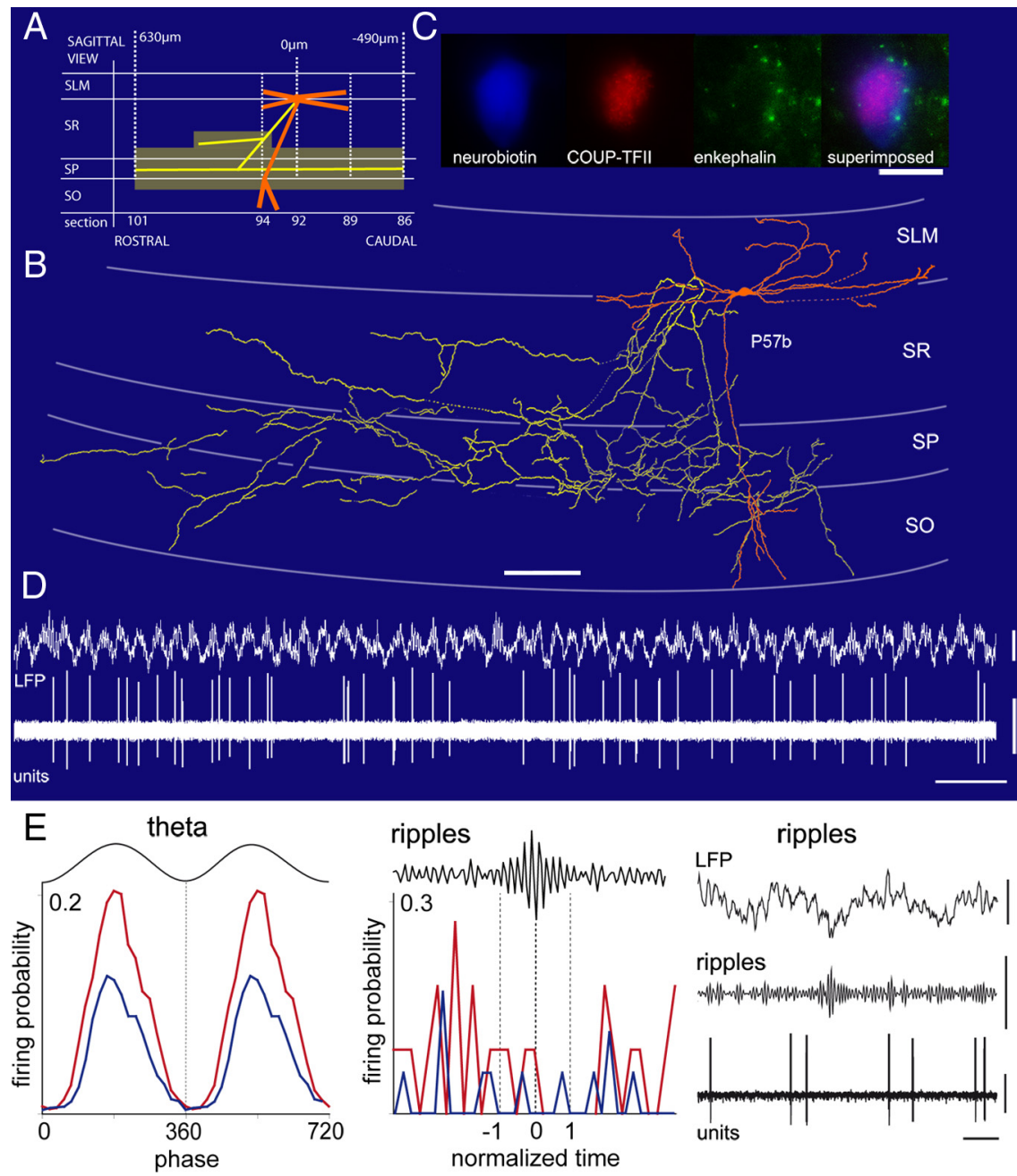

Figure 7. Axodendritic distribution and molecular composition of a basket cell (P57b) in stratum radiatum recorded in vivo. $\boldsymbol{A}$, Rostrocaudal projection of the axonal and dendritic arborizations of the neurobiotin-labeled cell. $\boldsymbol{B}$, Partial reconstruction of the basket cell; soma and dendrites (orange), axonal arborization (yellow) from 10 coronal sections (70 $\mu \mathrm{m}$ thickness). C, The basket cell was immunopositive for COUP-TFIl in the nucleus and the somatic membrane was decorated by enkephalin-immunopositive boutons. $\boldsymbol{D}$, In vivo firing pattern of the reconstructed cell during theta oscillations recorded in stratum pyramidale. $\boldsymbol{E}$, Firing patterns of identified radiatum-basket cells during spontaneous network oscillations. Theta phase (stratum pyramidale, left) and ripple episode (middle) firing probability histograms for radiatum-basket onset, highest amplitude and end of normalized ripple episodes are marked as $-1,0,1$, respectively (dotted lines). Right: Example trace of the local field potential (LFP, $0.3-300 \mathrm{~Hz}$ ), ripple episodes (filtered LFP, $90-140 \mathrm{~Hz}$ ) and spike train (units, radiatum; SP, stratum pyramidale; SO, stratum oriens. Scale bars: $\boldsymbol{B}, 100 \mu \mathrm{m} ; \boldsymbol{C}, 10 \mu \mathrm{m} ; \boldsymbol{D}, \mathrm{LFP} 0.5 \mathrm{mV}$, units $0.5 \mathrm{mV}$, horizontal $1 \mathrm{~s}$. $\boldsymbol{E}$, LFP $0.5 \mathrm{mV}$, ripples $0.2 \mathrm{mV}$, units $0.5 \mathrm{mV}$, horizontal $100 \mathrm{~ms}$.

tested the coexistence of CCK and PPTB by a triple fluorescent immunocytochemical reaction with the molecules CCK, CB and PPTB. From the tested cells immunopositive for PPTB $(n=$ 158)_-unlike in the neorcortex (Kaneko et al., 1998)—only a minor fraction $(12.6 \pm 0.4 \%)$ did not coexpress CCK (supplemental Table 2, available at www.jneurosci.org as supplemental material). Thus, cells with the molecular profile of the RADI cell may constitute a small, yet distinct interneuron population in the CA1 area.

During theta oscillations, the RADI cell fired just after the peak of the cycles recorded extracellularly in stratum pyramidale (Fig. 8 E; Table 2). Interestingly, during ripple oscillations the RADI cell was active in approximately half of the episodes (49\%), 

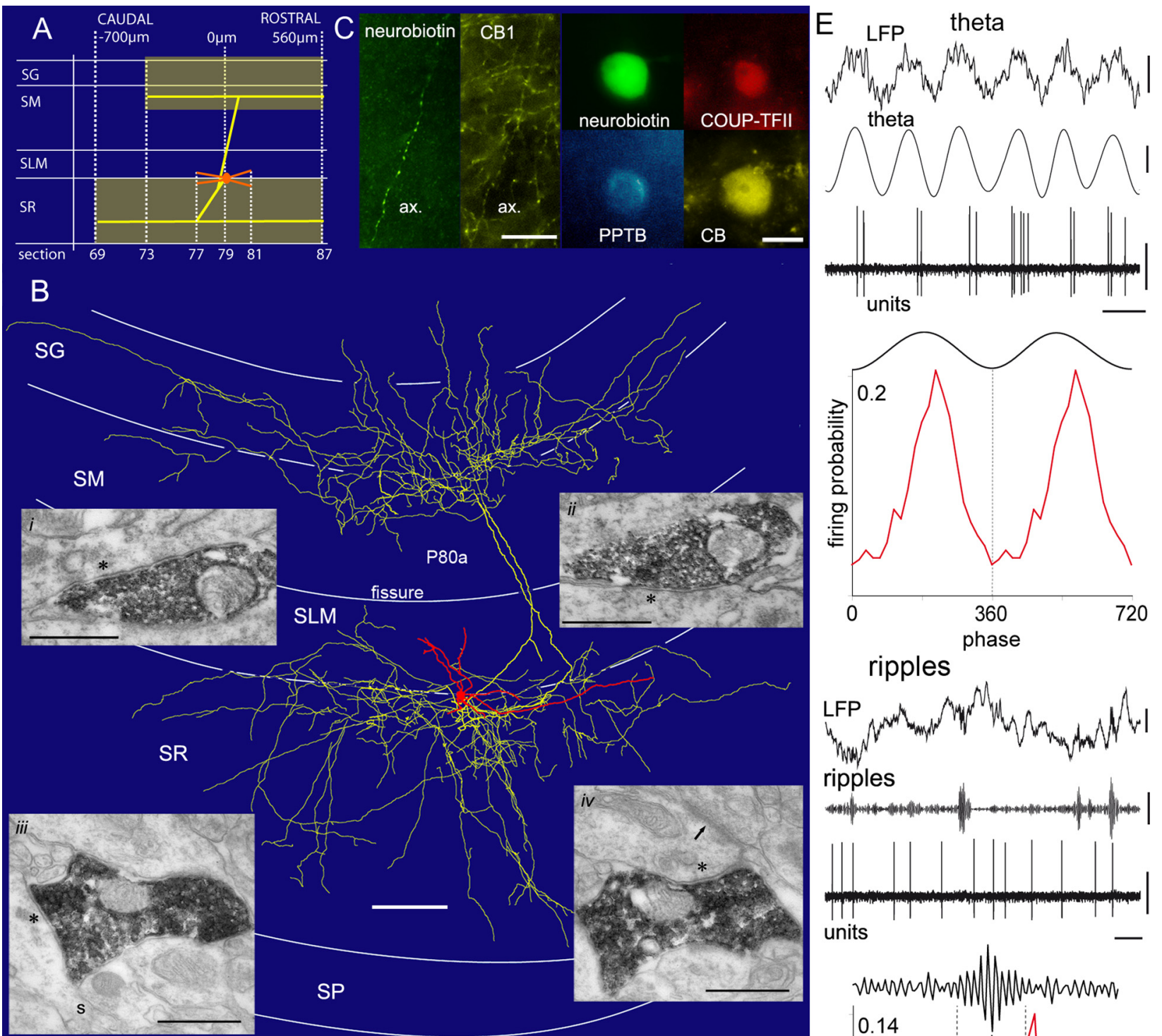

D

SP
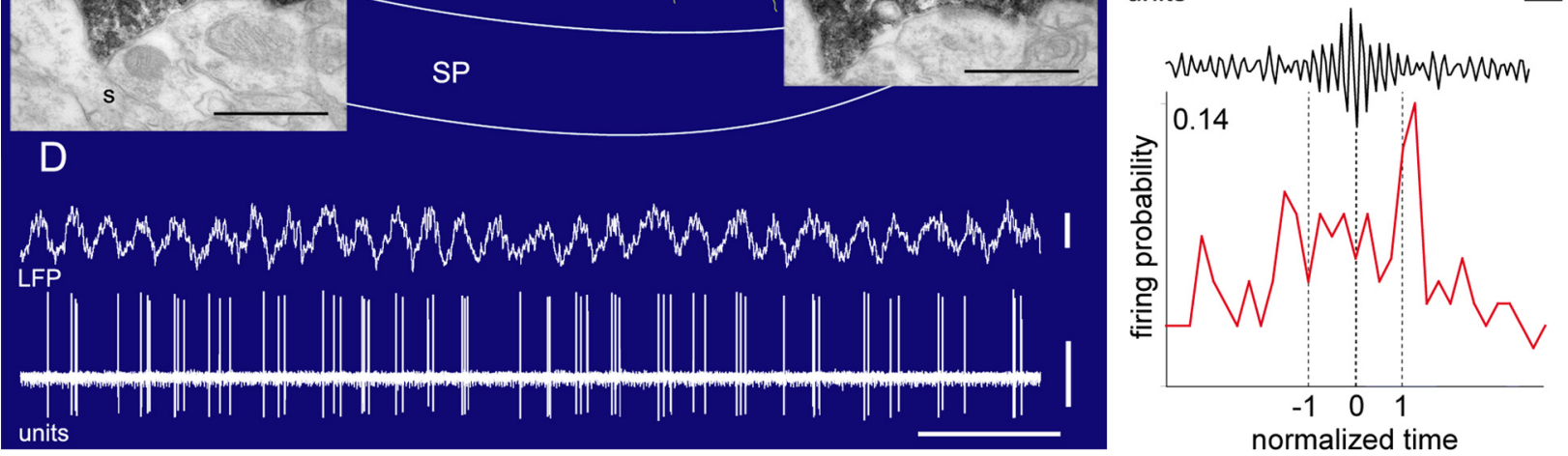

Figure 8. Axodendritic distribution and molecular composition of a RADI interneuron recorded in vivo. $\boldsymbol{A}$, Rostrocaudal projection of the axonal arborization of cell P80a. $\boldsymbol{B}$, Neurolucida reconstruction and synaptic targets of the cell. Soma and dendrites (complete, orange), axonal arborization (partial, yellow) from 10 coronal sections ( $70 \mu \mathrm{m}$ thickness). Bi, ii, A bouton in stratum granulosum forms synaptic junctions (asterisks) with two neighboring granule cell somata as seen in serial sections. Biii, iv, A bouton in stratum radiatum forms synaptic junctions onto a pyramidal cell dendritic shaft (identified by an emerging spine (s) and onto an interneuron dendritic shaft (identified by a type-I synapse, arrow) in serial sections. C, The RADI cell (P80a) was immunopositive for COUP-TFII, PPTB and calbindin in the soma. The axon (ax.) was immunopositive for the CB1 receptor. D, In vivo firing pattern of the RADI cell during theta oscillations recorded in stratum pyramidale. $\boldsymbol{E}$, Firing patterns of an identified RADI cell (P80a) during spontaneous network oscillations. Example traces of the local field potential (LFP, $0.3-300 \mathrm{~Hz}$ ), theta (stratum pyramidale, filtered LFP, 3-6 Hz) or ripple (filtered LFP, $90-140 \mathrm{~Hz}$ ) oscillations and spike trains (units, $0.8-5 \mathrm{kHz}$ ) during theta waves (theta, top) and ripples episodes (ripples, bottom). In the theta phase (top) firing probability histogram the same data are repeated in two cycles to indicate oscillations. The trough of the extracellularly recorded oscillations in stratum pyramidale are at $0^{\circ}, 360^{\circ}$ and $720^{\circ}$; bin size is $18^{\circ}$. For the ripple episode (bottom) firing probability histogram, the onset, highest amplitude and end of normalized ripple episodes are marked as $-1,0,1$, respectively (dotted lines). SG, stratum granulosum; SM, stratum moleculare; SLM, stratum lacunosum-moleculare; SR, stratum radiatum; SP, stratum pyramidale. Scale bars: $\boldsymbol{B}$, reconstruction $100 \mu \mathrm{m}$, micrographs $0.5 \mu \mathrm{m}$; C, soma $10 \mu \mathrm{m}$, axon $20 \mu \mathrm{m} ; \boldsymbol{D}$, LFP $0.5 \mathrm{mV}$, units $0.5 \mathrm{mV}$, horizontal $1 \mathrm{~s}$. E, LFP $0.5 \mathrm{mV}$, theta and ripples $0.2 \mathrm{mV}$, units $0.5 \mathrm{mV}$, horizontal $200 \mathrm{~ms}$.

in contrast to the neurogliaform and basket cells described here and to various other cell types reported in deep layers of the hippocampus (Klausberger et al., 2005; Jinno et al., 2007). In summary, the COUP-TFII-immunopositive identified interneu- rons discharged around the peak of theta oscillations in stratum pyramidale and did not significantly change their firing pattern during ripple episodes (Fig. 9A,B). In addition, they all discharged multiple spikes within the gamma $(30-80 \mathrm{~Hz})$ range (Fig. $9 C)$. 

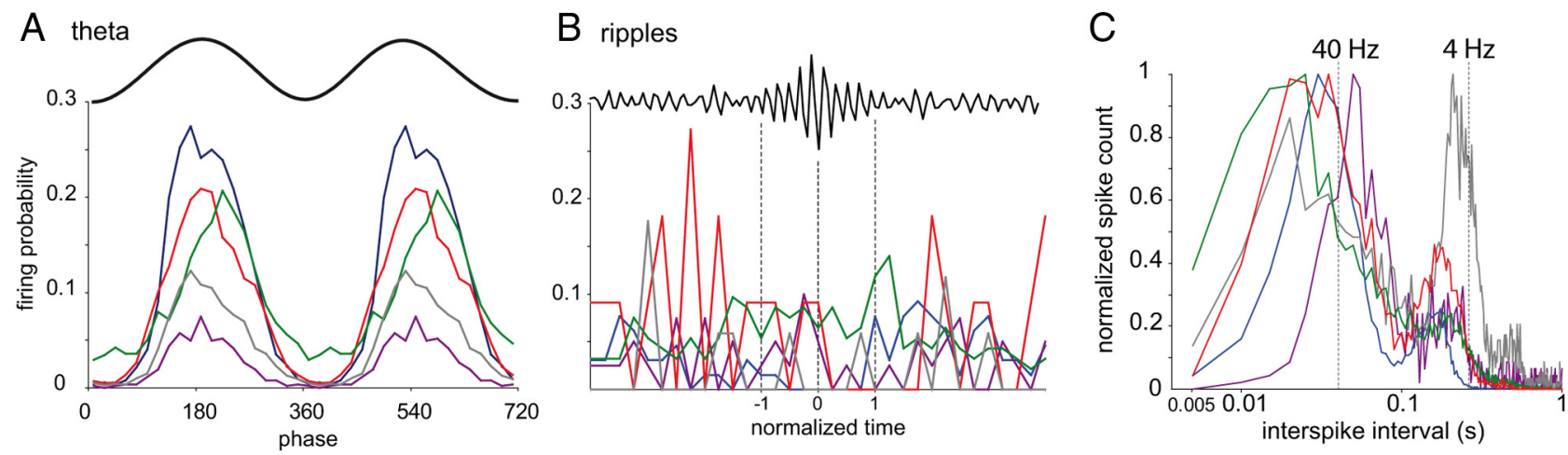

\section{P33a — neurogliaform, T126c — neurogliaform, P57b—basket, P75b—basket, P80a-RADI}

Figure 9. Summary of the spike-timing of identified COUP-TFIl immunopositive cells during network oscillations. $A, B$, Phase histograms for neurogliaform (T126C, P33a), radiatumbasket (P57b, P75b) and RADI (P80a) cells during theta ( $\boldsymbol{A}$ ) and ripple (B) oscillations. The same data are repeated in two cycles for theta. The troughs of the extracellularly recorded oscillations in stratum pyramidale are at $0^{\circ}, 360^{\circ}$, and $720^{\circ}$; bin size $18^{\circ}$. The onset, highest amplitude and end of normalized ripple episodes are marked as $-1,0,1$, respectively (dotted lines). C, Distributions of normalized interspike intervals for COUP-TFIl-expressing cells during theta oscillations. Note two peaks for all cells around gamma $(40 \mathrm{~Hz})$ and theta $(4 \mathrm{~Hz})$ bands.

\section{Discussion}

We found the COUP-TFII nuclear receptor in the adult forebrain in restricted populations of glutamatergic pyramidal cells and GABAergic cells. In the dorsal hippocampus, COUP-TFII was mainly expressed in GABAergic cells. These constituted a large fraction of GABAergic cells. Remarkably, the majority of the COUP-TFII-immunopositive interneuron population consists of only a few cell types: interneuron targeting interneurons (Acsády et al., 1996), ivy cells, a subset of basket cells and neurogliaform cells. The few COUP-TFII-immunopositive interneuron types recorded in vivo fired around the peak of theta oscillation in the pyramidal layer and did not change their firing rate during sharp waves.

\section{Embryonic origin of COUP-TFII GABAergic cells}

The precise spatiotemporal subpallial origin of GABAergic cells appears to specify their cell type fate (Marín and Rubenstein, 2003; Butt et al., 2005; Miyoshi et al., 2007). Accordingly, subpallial neuroepithelial domains defined by the expression of transcription factors generate distinct cell types. Cortical interneurons originated from the MGE migrate diffusely, whereas interneurons derived from the CGE migrate mainly into a caudal migratory stream (Yozu et al., 2005). Regarding COUP-TFII-expressing progenitors, COUP-TFII is highly enriched in the CGE and regulates the formation of the caudal migratory stream of interneurons during development (Kanatani et al., 2008). Furthermore, the restricted expression of COUP-TFII in only a few GABAergic cell types in the mature hippocampus, as shown here, suggests that it is a determinant in the generation of neuronal diversity.

The two members of the family, COUP-TFI and COUP-TFII show distinct and nonoverlapping expression profiles in the developing telencephalon, and both COUP-TFs are expressed in migrating cells (Tripodi et al., 2004; Kanatani et al., 2008). In light of the restricted expression of COUP-TFII in the CGE and dorsal MGE, it is plausible that COUP-TFII is involved in the specification of interneurons migrating from the CGE region in a similar way to the homeobox transcription factor Nkx6.2. The latter overlaps with COUP-TFII in the dorsal edge of the MGE and colocalizes with CR and SM in interneurons of the neocortex (Fogarty et al., 2007; Sousa et al., 2009).

During development, the COUP-TFII is also expressed in Cajal-Retzius cells, guiding their migration into the intermediate zone of the neocortex (Tripodi et al., 2004). Cajal-Retzius cells express reelin and play a critical role in corticogenesis (MarínPadilla, 1998). It is unlikely that the interneurons we found expressing COUP-TFII derive from Cajal-Retzius cells. First, Cajal-Retzius cells disappear with development and in the adult brain they are sparse or absent (Derer and Derer, 1990; Del Río et al., 1997; Mienville and Pesold, 1999). Second, unlike the cells we identified, Cajal-Retzius cells form type-I synapses and are thought to be glutamatergic (Radnikow et al., 2002). Thus, it is possible that the GABAergic reelin and COUP-TFII-immunopositive cells originated from the CGE, migrated and differentiated through the caudal migratory stream.

Radially oriented, bipolar or bitufted cells expressing CR originate mostly from the CGE (Xu et al., 2004; Butt et al., 2005) and several postnatal CR-expressing interneurons coexpressed COUP-TFII (Kanatani et al., 2008). In the hippocampus, COUP-TFII is associated with calretinin expression in a group of interneurons. It remains to be established whether the other interneurons we have identified here also originated from the CGE. The expression of COUP-TFII in the late migrating interneurons from the subventricular zone remains to be tested (Inta et al., 2008).

\section{Cell types expressing COUP-TFII in the adult hippocampus}

The COUP-TFII-expressing neurons in the dorsal hippocampus represented $30-40 \%$ of the total GABAergic neurons surpassing the PV- and/or SM-expressing populations (Jinno and Kosaka, 2006). Our anatomical characterization of the GABAergic cells indicates that $80-90 \%$ of COUP-TFII expression is accounted for by interneuron-selective interneurons $(\sim 40-45 \%)$, ivy cells $(\sim 30-35 \%)$ and neurogliaform cells $(\sim 10 \%)$. Ivy cells were described earlier (Fuentealba et al., 2008b), and partial information was reported for enkephalin-expressing interneuron-selective interneurons immunopositive for COUP-TFII (Fuentealba et al., 2008a). Here we have established that radiatum-retrohippocampal projection cells, subpopulations of CB- and CCK-expressing cells (Klausberger et al., 2005; Jinno et al., 2007), as well as neurogliaform cells comprise the COUP-TFII-expressing interneurons. Neurogliaform cells, which express $\alpha$-actinin-2 in stratum lacunosum-moleculare (Price et al., 2005), also express COUP-TFII, high membrane level of $\mathrm{GABA}_{\mathrm{A}}$ receptor $\alpha 1$ sub- 
unit and reelin, in addition to previously described nNOS and NPY (Price et al., 2005).

Another population of COUP-TFII-immunopositive cells expressed $\mathrm{CB}$, already known to be expressed by multiple interneuron types as well as by granule cells, CA1 and CA2 pyramidal cells (Gulyás and Freund, 1996; Jinno et al., 2007). Interestingly, during early developmental stages CB and COUP-TFII are already coexpressed (Kanatani et al., 2008). Among the CB-expressing interneurons, those in stratum oriens (Tóth and Freund, 1992; Jinno et al., 2007) were rarely immunopositive for COUP-TFII. Conversely, CB-expressing cells located in deep stratum radiatum commonly coexpressed COUP-TFII. These CB-expressing neurons, were not radiatum-retrohippocampal projection cells (Jinno et al., 2007), and also coexpressed PPTB and CCK. The recorded RADI cell, which coexpressed COUP-TFII, PPTB and $\mathrm{CB}$ is a potential distinct cell type. These features, described partly from a single recorded neuron, will need to be tested in further labeling experiments.

The most striking feature of the identified RADI cell was its large back-projection to the dentate gyrus. The direct synaptic innervation of granule cell somata and proximal dendrites suggests a strong influence of RADI cells on granule cells. Other GABAergic cells, such as neurogliaform cells (Price et al., 2005) and CCK-expressing perforant path-associated cells (Klausberger et al., 2005) also cross the fissure from the CA1, but none of these reached the granule cell bodies.

The theta modulated highest firing probability of the COUPTFII-expressing neurogliaform, basket and RADI cells presented here tend to align with the peak of theta oscillations in stratum pyramidale. However, other COUP-TFII-expressing cells such as ivy, enkephalin-expressing, or radiatum-retrohippocampal cells tend to fire at or close to the trough of theta (Fuentealba et al., 2008a,b; Jinno et al., 2007). Therefore, the theta firing phase is not uniform across COUP-TFII-expressing neurons and may depend on their synaptic connectivity in the network.

\section{Reelin expression in the hippocampus}

All tested neurogliaform cells expressed reelin in stratum lacunosum-moleculare. However, reelin was not detected in the related COUP-TFII-expressing ivy cells, which occupy other hippocampal layers (i.e., strata oriens, pyramidale and radiatum). In a previous study, we distinguished ivy cells from neurogliaform cells based on major differences in glutamatergic inputs as predicted from their dendritic distribution in either strata oriens and radiatum or lacunosum-moleculare, respectively. In the current study, we defined two further differences. First, neurogliaform cells preferentially discharged at the peak of theta oscillations recorded in stratum pyramidale, whereas ivy cells discharged at the trough of theta waves (Fuentealba et al., 2008b), similar to other interneurons that innervate strata radiatum and oriens, like bistratified, double projection and trilaminar cells (Klausberger and Somogyi, 2008). Further in vivo recordings from identified neurogliaform cells will be necessary to confirm this conclusion based at present on two cells. Second, all neurogliaform cells recorded and labeled in vitro expressed reelin, whereas from the laminar distribution of reelin-expressing somata and colabeling experiments, it is clear that few, if any, ivy cells express reelin. Thus, reelin is expressed in neurogliaform cells, but not in the related ivy cells. These results add a molecular criterion for the identification of these two cell types, and appear to be in contrast to the reported presence of reelin in neocortical CR- or CBexpressing cells (Alcántara et al., 1998; Pesold et al., 1999).
Reelin, expressed by Cajal-Retzius cells (Ogawa et al., 1995; Frotscher, 1998), is fundamental for the definition of cortical layers (Hamburgh, 1963; Zhao et al., 2004), and acts as a stop signal for migrating neurons (Del Río et al., 1997; Chai et al., 2009). In the adult dorsal CA1 region, we detected reelin in neurogliaform cells, and in the alveus/stratum oriens expressed in putative oriens-lacunosum-moleculare (O-LM) cells coexpressing reelin and SM shown here and mGluR1 $\alpha$ (our unpublished observation) (Ramos-Moreno et al., 2006). O-LM cells innervate stratum lacunosum-moleculare, where they are likely to release reelin from their axons together with the neurogliaform cells. The preferential firing of O-LM cells at the trough (Klausberger et al., 2003) and of neurogliaform cells at the peak of stratum pyramidale theta oscillations, probably makes little difference for the slow signaling mechanism of reelin. The temporal specialization by O-LM and neurogliaform cells could be important for the faster action of GABA in stratum lacunosum-moleculare, particularly as O-LM cells innervate neurogliaform cells (Elfant et al., 2008). The O-LM cells may contribute to hyperpolarization of pyramidal cell apical dendrites when the local field potential is most negative in stratum pyramidale (distal apical dendrites relatively hyperpolarized), whereas neurogliaform cells release GABA when the stratum pyramidale local field potential is most positive (distal dendrites most depolarized) and the entorhinal glutamatergic input to stratum lacunosum-moleculare is presumably most active. This apparent specificity in temporal segregation of spatially converging GABAergic inputs may represent a striking example of temporal complementarities in cortical circuits, delivered by distinct interneurons (Somogyi and Klausberger, 2005).

\section{References}

Acsády L, Görcs TJ, Freund TF (1996) Different populations of vasoactive intestinal polypeptide-immunoreactive interneurons are specialized to control pyramidal cells or interneurons in the hippocampus. Neuroscience 73:317-334.

Alcántara S, Ruiz M, D’Arcangelo G, Ezan F, de Lecea L, Curran T, Sotelo C, Soriano E (1998) Regional and cellular patterns of reelin mRNA expression in the forebrain of the developing and adult mouse. J Neurosci 18:7779-7799.

Armentano M, Chou SJ, Tomassy GS, Leingärtner A, O’Leary DD, Studer M (2007) COUP-TFI regulates the balance of cortical patterning between frontal/motor and sensory areas. Nat Neurosci 10:1277-1286.

Barry PH (1994) JPCalc, a software package for calculating liquid junction potential corrections in patch-clamp, intracellular, epithelial and bilayer measurements and for correcting junction potential measurements. J Neurosci Methods 51:107-116.

Bartos M, Vida I, Jonas P (2007) Synaptic mechanisms of synchronized gamma oscillations in inhibitory interneuron networks. Nat Rev Neurosci 8:45-56.

Batista-Brito R, Fishell G (2009) The developmental integration of cortical interneurons into a functional network. Curr Top Dev Biol 87:81-118.

Blasco-Ibáñez JM, Martínez-Guijarro FJ, Freund TF (1998) Enkephalincontaining interneurons are specialized to innervate other interneurons in the hippocampal CA1 region of the rat and guinea-pig. Eur J Neurosci 10:1784-1795.

Bourdeau ML, Morin F, Laurent CE, Azzi M, Lacaille JC (2007) Kv4.3mediated A-type $\mathrm{K}^{+}$currents underlie rhythmic activity in hippocampal interneurons. J Neurosci 27:1942-1953.

Butt SJ, Fuccillo M, Nery S, Noctor S, Kriegstein A, Corbin JG, Fishell G (2005) The temporal and spatial origins of cortical interneurons predict their physiological subtype. Neuron 48:591-604.

Butt SJ, Sousa VH, Fuccillo MV, Hjerling-Leffler J, Miyoshi G, Kimura S, Fishell G (2008) The requirement of Nkx2-1 in the temporal specification of cortical interneuron subtypes. Neuron 59:722-732.

Buzsáki G (2002) Theta oscillations in the hippocampus. Neuron 33:325-340.

Caputi A, Rozov A, Blatow M, Monyer H (2009) Two calretinin-positive 
GABAergic cell types in layer 2/3 of the mouse neocortex provide different forms of inhibition. Cereb Cortex 19:1345-1359.

Chai X, Förster E, Zhao S, Bock HH, Frotscher M (2009) Reelin stabilizes the actin cytoskeleton of neuronal processes by inducing $\mathrm{n}$-cofilin phosphorylation at serine3. J Neurosci 29:288-299.

Cobb SR, Buhl EH, Halasy K, Paulsen O, Somogyi P (1995) Synchronization of neuronal activity in hippocampus by individual GABAergic interneurons. Nature 378:75-78.

Csicsvari J, Hirase H, Czurkó A, Mamiya A, Buzsáki G (1999) Oscillatory coupling of hippocampal pyramidal cells and interneurons in the behaving rat. J Neurosci 19:274-287.

Del Río JA, Heimrich B, Borrell V, Förster E, Drakew A, Alcántara S, Nakajima K, Miyata T, Ogawa M, Mikoshiba K, Derer P, Frotscher M, Soriano E (1997) A role for Cajal-Retzius cells and reelin in the development of hippocampal connections. Nature 385:70-74.

Derer P, Derer M (1990) Cajal-Retzius cell ontogenesis and death in mouse brain visualized with horseradish peroxidase and electron microscopy. Neuroscience 36:839-856.

Elfant D, Pál BZ, Emptage N, Capogna M (2008) Specific inhibitory synapses shift the balance from feedforward to feedback inhibition of hippocampal CA1 pyramidal cells. Eur J Neurosci 27:104-113.

Flames N, Marín O (2005) Developmental mechanisms underlying the generation of cortical interneuron diversity. Neuron 46:377-381.

Fogarty M, Grist M, Gelman D, Marín O, Pachnis V, Kessaris N (2007) Spatial genetic patterning of the embryonic neuroepithelium generates GABAergic interneuron diversity in the adult cortex. J Neurosci 27:10935-10946.

Freund TF, Buzsáki G (1996) Interneurons of the hippocampus. Hippocampus 6:347-470.

Frotscher M (1998) Cajal-Retzius cells, Reelin, and the formation of layers. Curr Opin Neurobiol 8:570-575.

Fuentealba P, Tomioka R, Dalezios Y, Márton LF, Studer M, Rockland K, Klausberger T, Somogyi P (2008a) Rhythmically active enkephalinexpressing GABAergic cells in the CA1 area of the hippocampus project to the subiculum and preferentially innervate interneurons. J Neurosci 28:10017-10022.

Fuentealba P, Begum R, Capogna M, Jinno S, Marton LF, Csicsvari J, Thomson A, Somogyi P, Klausberger T (2008b) Ivy cells: a population of nitricoxide-producing, slow-spiking GABAergic neurons and their involvement in hippocampal network activity. Neuron 57:917-929.

Gulyás AI, Freund TF (1996) Pyramidal cell dendrites are the primary targets of calbindin D28k-immunoreactive interneurons in the hippocampus. Hippocampus 6:525-534.

Gulyás AI, Hájos N, Freund TF (1996) Interneurons containing calretinin are specialized to control other interneurons in the rat hippocampus. J Neurosci 16:3397-3411.

Hamburgh M (1963) Analysis of the postnatal developmental effects of "Reeler," a neurological mutation in mice. A study in developmental genetics. Dev Biol 19:165-185.

Hestrin S, Armstrong WE (1996) Morphology and physiology of cortical neurons in layer I. J Neurosci 16:5290-5300.

Inta D, Alfonso J, von Engelhardt J, Kreuzberg MM, Meyer AH, van Hooft JA, Monyer H (2008) Neurogenesis and widespread forebrain migration of distinct GABAergic neurons from the postnatal subventricular zone. Proc Natl Acad Sci U S A 105:20994-20999.

Jinno S, Kosaka T (2002) Patterns of expression of calcium binding proteins and neuronal nitric oxide synthase in different populations of hippocampal GABAergic neurons in mice. J Comp Neurol 449:1-25.

Jinno S, Kosaka T (2006) Cellular architecture of the mouse hippocampus: a quantitative aspect of chemically defined GABAergic neurons with stereology. Neurosci Res 56:229-245.

Jinno S, Klausberger T, Marton LF, Dalezios Y, Roberts JD, Fuentealba P, Bushong EA, Henze D, Buzsáki G, Somogyi P (2007) Neuronal diversity in GABAergic long-range projections from the hippocampus. J Neurosci 27:8790-8804.

Kanatani S, Yozu M, Tabata H, Nakajima K (2008) COUP-TFII is preferentially expressed in the caudal ganglionic eminence and is involved in the caudal migratory stream. J Neurosci 28:13582-13591.

Kaneko T, Murashima M, Lee T, Mizuno N (1998) Characterization of neocortical non-pyramidal neurons expressing preprotachykinins A and B: a double immunofluorescence study in the rat. Neuroscience 86:765-781.

Katona I, Sperlágh B, Sík A, Käfalvi A, Vizi ES, Mackie K, Freund TF (1999)
Presynaptically located $\mathrm{CB} 1$ cannabinoid receptors regulate GABA release from axon terminals of specific hippocampal interneurons. J Neurosci 19:4544-4558.

Kawaguchi Y, Kondo S (2002) Parvalbumin, somatostatin and cholecystokinin as chemical markers for specific GABAergic interneuron types in the rat frontal cortex. J Neurocytol 31:277-287.

Kawaguchi Y, Kubota Y (1997) GABAergic cell subtypes and their synaptic connections in rat frontal cortex. Cereb Cortex 7:476-486.

Kim BJ, Takamoto N, Yan J, Tsai SY, Tsai MJ (2009) Chicken ovalbumin upstream promoter-transcription factor II (COUP-TFII) regulates growth and patterning of the postnatal mouse cerebellum. Dev Biol 326:378-391.

Klausberger T, Somogyi P (2008) Neuronal diversity and temporal dynamics: the unity of hippocampal circuit operations. Science 321:53-57.

Klausberger T, Magill PJ, Márton LF, Roberts JD, Cobden PM, Buzsáki G, Somogyi P (2003) Brain-state- and cell-type-specific firing of hippocampal interneurons in vivo. Nature 421:844-848.

Klausberger T, Marton LF, O’Neill J, Huck JH, Dalezios Y, Fuentealba P, Suen WY, Papp E, Kaneko T, Watanabe M, Csicsvari J, Somogyi P (2005) Complementary roles of cholecystokinin- and parvalbumin-expressing GABAergic neurons in hippocampal network oscillations. J Neurosci 25:9782-9793.

Liodis P, Denaxa M, Grigoriou M, Akufo-Addo C, Yanagawa Y, Pachnis V (2007) Lhx6 activity is required for the normal migration and specification of cortical interneuron subtypes. J Neurosci 27:3078-3089.

Marín O, Rubenstein JL (2001) A long, remarkable journey: tangential migration in the telencephalon. Nat Rev Neurosci 2:780-790.

Marín O, Rubenstein JL (2003) Cell migration in the forebrain. Annu Rev Neurosci 26:441-483.

Marín-Padilla M (1998) Cajal-Retzius cells and the development of the neocortex. Trends Neurosci 21:64-71.

Mienville JM, Pesold C (1999) Low resting potential and postnatal upregulation of NMDA receptors may cause Cajal-Retzius cell death. J Neurosci 19:1636-1646.

Miyashita T, Rockland KS (2007) GABAergic projections from the hippocampus to the retrosplenial cortex in the rat. Eur J Neurosci 26:1193-1204.

Miyoshi G, Butt SJ, Takebayashi H, Fishell G (2007) Physiologically distinct temporal cohorts of cortical interneurons arise from telencephalic Olig2expressing precursors. J Neurosci 27:7786-7798.

Morales M, Bloom FE (1997) The 5-HT3 receptor is present in different subpopulations of GABAergic neurons in the rat telencephalon. J Neurosci 17:3157-3167.

Nery S, Fishell G, Corbin JG (2002) The caudal ganglionic eminence is a source of distinct cortical and subcortical cell populations. Nat Neurosci 5:1279-1287.

Ogawa M, Miyata T, Nakajima K, Yagyu K, Seike M, Ikenaka K, Yamamoto H, Mikoshiba K (1995) The reeler gene-associated antigen on CajalRetzius neurons is a crucial molecule for laminar organization of cortical neurons. Neuron 14:899-912.

Oláh S, Fule M, Komlósi G, Varga C, Báldi R, Barzó P, Tamás G (2009) Regulation of cortical microcircuits by unitary GABA-mediated volume transmission. Nature 461:1278-1281.

Park JI, Tsai SY, Tsai MJ (2003) Molecular mechanism of chicken ovalbumin upstream promoter-transcription factor (COUP-TF) actions. Keio J Med 52:174-181.

Pawelzik H, Hughes DI, Thomson AM (2002) Physiological and morphological diversity of immunocytochemically defined parvalbumin- and cholecystokinin-positive interneurones in CA1 of the adult rat hippocampus. J Comp Neurol 443:346-367.

Pereira FA, Qiu Y, Zhou G, Tsai MJ, Tsai SY (1999) The orphan nuclear receptor COUP-TFII is required for angiogenesis and heart development. Genes Dev 13:1037-1049.

Pesold C, Liu WS, Guidotti A, Costa E, Caruncho HJ (1999) Cortical bitufted, horizontal, and Martinotti cells preferentially express and secrete reelin into perineuronal nets, nonsynaptically modulating gene expression. Proc Natl Acad Sci U S A 96:3217-3222.

Price CJ, Cauli B, Kovacs ER, Kulik A, Lambolez B, Shigemoto R, Capogna M (2005) Neurogliaform neurons form a novel inhibitory network in the hippocampal CA1 area. J Neurosci 25:6775-6786.

Radnikow G, Feldmeyer D, Lübke J (2002) Axonal projection, input and 
output synapses, and synaptic physiology of Cajal-Retzius cells in the developing rat neocortex. J Neurosci 22:6908-6919.

Ramos-Moreno T, Galazo MJ, Porrero C, Mártinez-Cerdeño V, Clascá $\mathrm{F}$ (2006) Extracellular matrix molecules and synaptic plasticity: immunomapping of intracellular and secreted Reelin in the adult rat brain. Eur J Neurosci 23:401-422.

Rodriguez E, George N, Lachaux JP, Martinerie J, Renault B, Varela FJ (1999) Perception's shadow: long-distance synchronization of human brain activity. Nature 397:430-433.

Simon A, Oláh S, Molnár G, Szabadics J, Tamás G (2005) Gap-junctional coupling between neurogliaform cells and various interneuron types in the neocortex. J Neurosci 25:6278-6285.

Singer W, Gray CM (1995) Visual feature integration and the temporal correlation hypothesis. Annu Rev Neurosci 18:555-586.

Somogyi P, Klausberger T (2005) Defined types of cortical interneurone structure space and spike timing in the hippocampus. J Physiol 562:9-26.

Sousa VH, Miyoshi G, Hjerling-Leffler J, Karayannis T, Fishell G (2009) Characterization of Nkx6-2-derived neocortical interneuron lineages. Cereb Cortex 19 (Suppl 1):i1-i10.

Sugiyama S, Di Nardo AA, Aizawa S, Matsuo I, Volovitch M, Prochiantz A, Hensch TK (2008) Experience-dependent transfer of Otx2 homeoprotein into the visual cortex activates postnatal plasticity. Cell 134:508-520.

Sussel L, Marin O, Kimura S, Rubenstein JL (1999) Loss of Nkx2.1 homeobox gene function results in a ventral to dorsal molecular respecifi- cation within the basal telencephalon: evidence for a transformation of the pallidum into the striatum. Development 126:3359-3370.

Tomioka R, Rockland KS (2006) Improved Golgi-like visualization in retrogradely projecting neurons after EGFP-adenovirus infection in adult rat and monkey. J Histochem Cytochem 54:539-548.

Tóth K, Freund TF (1992) Calbindin D28k-containing nonpyramidal cells in the rat hippocampus: their immunoreactivity for GABA and projection to the medial septum. Neuroscience 49:793-805.

Tripodi M, Filosa A, Armentano M, Studer M (2004) The COUP-TF nuclear receptors regulate cell migration in the mammalian basal forebrain. Development 131:6119-6129.

Wonders CP, Anderson SA (2006) The origin and specification of cortical interneurons. Nat Rev Neurosci 7:687-696.

Xu Q, Cobos I, De La Cruz E, Rubenstein JL, Anderson SA (2004) Origins of cortical interneuron subtypes. J Neurosci 24:2612-2622.

Yozu M, Tabata H, Nakajima K (2005) The caudal migratory stream: a novel migratory stream of interneurons derived from the caudal ganglionic eminence in the developing mouse forebrain. J Neurosci 25:72687277.

Zar JH (1999) Biostatistical analysis, Ed 4. Upper Saddle River, NJ: Prentice Hall.

Zhao S, Chai X, Förster E, Frotscher M (2004) Reelin is a positional signal for the lamination of dentate granule cells. Development 131:5117-5125. 